\title{
CORPORATE FOREIGN CORRUPT PRACTICES AND DIRECTOR LIABILITY
}

\author{
PAUL BLYSCHAK ${ }^{*}$
}

This article examines the various forms of potential liability faced by directors in their capacity as such in connection with corrupt practices engaged in by the corporations they serve. Although generally little discussed to date, Canadian directors do face potential civil liability associated with contraventions of the Corruption of Foreign Public Officials Act that are particular to their status as directors of a corporation. This article thus highlights this particular area of corporate law by reviewing both Canadian jurisprudence and American case law to decipher what lessons Canadian directors can learn in the absence of Canadian precedent similarly on point. Several key cases are highlighted and various risk mitigation strategies available to Canadian directors to guard against these potential liabilities are also discussed.
Cet article examine les diverses formes de responsabilité potentielle des administrateurs concernant les pratiques de corruption des entreprises sur le conseil desquels ils siègent. Bien que le sujet ait été très peu traité à ce jour, les administrateurs canadiens peuvent être tenus civilement responsables d'infractions en vertu de la Loi sur la corruption d'agents publics étrangers spécifiques à leur statut d'administrateurs d'une entreprise. Cet article souligne cet aspect particulier du droit des sociétés en examinant à la fois la jurisprudence canadienne et américaine dans le but de déchiffrer les leçons que les administrateurs canadiens peuvent tirer de l'absence de précédents canadiens semblables. Plusieurs causes clés sont mises en avant ainsi que diverses stratégies d'atténuation des risques auxquelles les administrateurs canadiens peuvent avoir recours pour se protéger de cette responsabilité potentielle.

\section{TABLE OF ConTENTS}

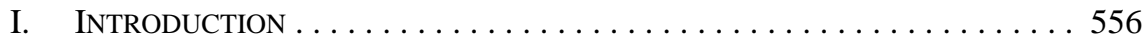

II. THE CORRUPTION OF FOREIGN PUBLIC OFFICIALS ACT

AND THE CRIMINAL CODE . . . . . . . . . . . . . . . . . . . . . . . 558

III. Directors' Duties Under CANAdian LAW $\ldots \ldots \ldots \ldots \ldots \ldots . \ldots 59$

IV. Relevant United States Case Law $\ldots \ldots \ldots \ldots \ldots \ldots \ldots \ldots . \ldots \ldots$

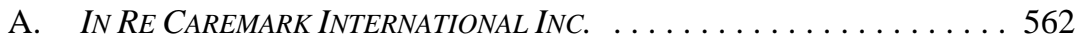

B. STONE V. RITTER AND IN RE DOW ................. 565

V. DIRECTORS' DUTIES AND CORPORATE CORRUPTION OF Foreign Public OfFicials ACt Violations $\ldots \ldots \ldots \ldots \ldots \ldots 68$

VI. DiRECTORS' DUTIES AND ANTI-CORRUPTION

Policies AND PROCEDURES . . . . . . . . . . . . . . . . . . . . 571

VII. DiRECTORS’ DUtIES AND SPECIAL INVESTIGATIONS $\ldots \ldots \ldots \ldots \ldots . \ldots 576$

VIII. DIRECTOR LIABILITY UNDER SECURITIES LAWS

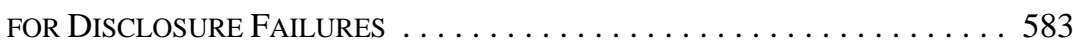

A. DRYWALL V. SNC-LAVALIN GROUP INC. . . . . . . . . . . . . . 583

B. Securities Class Actions in CANAdA ............... 585

C. DiRECTOR CiVIL LiABILITY FOR DisClOSURE FAILURES . . . . . . 587

D. DiRECTOR REGULATORY OR QUASI-CRIMINAL LIABILITY FOR DisCLOSURE FAILURES . . . . . . . . . . . . . . . . . . . . . 590

IX. CONCLUSION ................................... 597

Blake, Cassels \& Graydon LLP. Paul Blyschak is called to the bar in Alberta, New York State and New South Wales. He would like to thank Ryan MacIsaac and Douglas Scott for their assistance in researching and preparing this article. 


\section{INTRODUCTION}

With the recent tribulations of Niko Resources Ltd., Griffiths Energy International Inc. and SNC-Lavalin Group Inc. making front-page headlines, ${ }^{1}$ compliance with Canada's Corruption of Foreign Public Officials Act ${ }^{2}$ has quickly become a main priority for Canadian companies with foreign operations, assets, or business partners, including, in particular resource companies and their service providers. Whereas for over a decade the CFPOA largely lay dormant and unnoticed, one now might be hard-pressed to identify a corporate executive of a Canadian corporation with foreign interests who is not at least topically familiar with the CFPOA and its prohibition of corrupt practices involving foreign public officials.

It is a trite observation that a director of a corporation may incur liability under the CFPOA where he or she engages directly in corrupt practices or is wilfully blind to corrupt practices engaged in by an agent on their behalf. ${ }^{3}$ But such potential liability is not in any manner related to or contingent on the director being a director of a corporation (or any other position or authority he or she may hold). It is the same potential liability faced by any other person subject to the jurisdiction of Canadian courts and the CFPOA's criminalization of corrupt practices. Stated differently, the director would be criminally liable as an individual and not in any manner in the person's capacity as a director.

By contrast, although generally little discussed to date, Canadian directors do face potential civil liability associated with contraventions of the CFPOA which are particular to their status as directors of a corporation. Specifically, they face potential liability for breaches of their duty of care to the corporation as its director where it can be established that the breach of the director's duty either contributed to or failed to prevent the corporation from engaging in corrupt practices. This liability is subject to exposure, inter alia, through a derivative shareholder action instituted against the director or board of directors on the corporation's behalf. ${ }^{4}$

Furthermore, directors may also face additional potential liability in connection with suspected or proven corrupt practices engaged in by the corporation depending on the

See e.g. Greg McArthur, “Niko Resources: Ottawa’s corruption test case,” The Globe and Mail (25 August 2011), online: The Globe and Mail <http://www.theglobeandmail.com/report-on-business/robmagazine/niko-resources-ottawas-corruption-test-case/article542842/>; Kelly Cryderman, "Judge approves \$10.35-million fine for Griffiths Energy in bribery case,” The Globe and Mail (25 January 2013), online: The Globe and Mail <http://www.theglobeandmail.com/report-on-business/industrynews/the-law-page/judge-approves-1035-million-fine-for-griffiths-energy-in-bribery-case/ article7858675/>; Sophie Cousineau \& Jeff Gray, "SNC-Lavalin offers immunity to 'get to the bottom of' scandal," The Globe and Mail (27 May 2013), online: The Globe and Mail <http://www.the globe andmail.com/report-on-business/snc-lavalin-offers-immunity-to-get-to-the-bottom-of-scandal/ article12165964/>.

$2 \quad$ SC 1998, с 34 [CFPOA].

$3 \quad$ See Paul Blyschak \& John Boscariol, "Understanding and Mitigating Your Third Party Corruption Risk Under Canada's Corruption of Foreign Public Officials Act" (2013) 22:4 Canadian Corporate Counsel 57.

$4 \quad$ Canada Business Corporations Act, RSC 1985, c C-44, s 239 [CBCA]; Ontario Business Corporations Act, RSO 1990, c B.16, s 246 [OBCA]; Business Corporations Act, RSA 2000, c B-9, s 240 [ABCA]; Business Corporations Act, SBC 2002, c 57 [BCBCA]. See also BCE Inc v 1976 Debentureholders, 2008 SCC 69, [2008] 3 SCR 560 at para 44 [BCE], noting that the duty of care is not owed solely to the corporation and therefore "may be the basis for liability to other stakeholders in accordance with principles governing the law of tort and extracontractual liability." 
response to such suspected or proven corrupt practices once discovered. First, directors may face additional potential liability under their duty of care to the corporation should the corporation fail to properly investigate and respond to the suspected or proven corrupt practices. Second, where a corporation is subject to disclosure requirements, directors face additional potential liability under securities laws should the corporation fail to comply with applicable disclosure requirements in connection with the suspected or proven corrupt practices. In the former case, such liability is again subject to exposure, inter alia, through a derivative shareholder action instituted against the director or board of directors on the corporation's behalf. In the latter case, such potential liability is subject to exposure, inter alia, through an investor class action instituted against the director or board of directors under applicable securities laws. And finally, Canadian directors may also face possible regulatory or quasi-criminal liability under securities laws in connection with disclosure failures related to suspected or proven corrupt practices.

This article takes a closer look at these various forms of potential liability faced by directors in their capacity as such in connection with corrupt practices engaged in by the corporations they serve. This begins, first, with a high level review of the prohibitions imposed by the CFPOA and the corresponding corporate liability provisions of the Criminal Code. ${ }^{5}$ This article next examines directors' duties under Canadian law, including decisions of the Supreme Court of Canada on this point. This is followed by a review of several United States decisions considering the scope and substance of directors' duties in the context of corporate compliance failures under legal regimes similar to the CFPOA. These decisions are then compared to Canadian case law and statute to decipher what lessons Canadian directors can take from such case law in the absence of Canadian precedent similarly on point. Part VI of this article then reviews the conviction of Niko Resources Ltd. to examine how Canadian directors may mitigate against the risk of anti-corruption compliance failures through the implementation and enforcement of anti-corruption policies and procedures. Similarly, Part VII reviews the more recent conviction of Griffiths Energy International Inc. to consider the requirements of a director's duty of care once suspected or proven corrupt practices by a corporation or its representatives come to light. Finally, Part VIII examines the various civil regulatory and quasi-criminal liabilities faced by Canadian directors under securities laws in connection with disclosure failures relating to suspected or proven corrupt practices, including in reference to the class action lawsuit instituted against SNC-Lavalin and a number of its directors and officers.

The goal of this article is to advance discussion of the following: (1) the potential liabilities faced by Canadian directors in connection with contraventions of the CFPOA which are particular to their status as directors of a corporation; and (2) various risk mitigation strategies available to Canadian directors to guard against these potential liabilities. Where appropriate, this article also discusses various difficulties and complexities associated with foreign corrupt practices risk and cautions against the adoption of too strict or demanding a standard in respect of either the ability of directors: (1) to police and prevent foreign corrupt practices engaged in by the corporations they serve; or (2) to timely or definitively identify foreign corrupt practices engaged in by the corporations they serve. 


\section{The Corruption of Foreign Public Officals ACt AND THE CRIMINAL CODE}

Generally speaking, the CFPOA imposes criminal and monetary liability on individuals and entities that engage in bribery or other corruption of foreign public officials. Section 3(1) is the "centrepiece" of the Act and provides that:

(1) Every person commits an offence who, in order to obtain or retain an advantage in the course of business, directly or indirectly gives, offers or agrees to give or offer a loan, reward, advantage or benefit of any kind to a foreign public official or to any person for the benefit of a foreign public official

(a) as consideration for an act or omission by the official in connection with the performance of the official's duties or functions; or

(b) to induce the official to use his or her position to influence any acts or decisions of the foreign state or public international organization for which the official performs duties or functions. ${ }^{6}$

In addition, Bill S-14, recently enacted and effective 19 June 2013, added a corresponding "books and records" offence to the CFPOA. ${ }^{7}$ Bill S-15 makes it a criminal offence, "for the purpose of bribing a foreign public official ... or for the purpose of hiding that bribery," to engage in any of the following accounting practices:

(a) establishes or maintains accounts which do not appear in any of the books and records that they are required to keep in accordance with applicable accounting and auditing standards;

(b) makes transactions that are not recorded in those books and records or that are inadequately identified in them;

(c) records non-existent expenditures in those books and records;

(d) enters liabilities with incorrect identification of their object in those books and records;

(e) knowingly uses false documents; or

(f) intentionally destroys accounting books and records earlier than permitted by law. ${ }^{8}$

Lastly, in order for a corporation to be criminally liable under the Criminal Code, at least one of the three alternate standards imposed by Criminal Code section 22.2 must be satisfied. Specifically, section 22.2 provides: 
22.2 In respect of an offence that requires the prosecution to prove fault - other than negligence - an organization is a party to the offence if, with the intent at least in part to benefit the organization, one of its senior officers:

(a) acting within the scope of their authority, is a party to the offence;

(b) having the mental state required to be a party to the offence and acting within the scope of their authority, directs the work of other representatives of the organization so that they do the act or make the omission specified in the offence; or

(c) knowing that a representative of the organization is or is about to be a party to the offence, does not take all reasonable measures to stop them from being a party to the offence. ${ }^{9}$

"Senior officer" is defined by section 2 of the Criminal Code to mean "a representative who plays an important role in the establishment of [a corporation's] policies or is responsible for managing an important aspect of the [corporation]'s activities and ... includes a director, its chief executive officer and its chief financial officer."10 "Representative” is defined by section 2 of the Criminal Code to mean "a director, partner, employee, member, agent or contractor" of a corporation. ${ }^{11}$

Therefore, generally speaking, a corporation will be liable for corrupt practices under the CFPOA and the Criminal Code where one of its "senior officers" engages in the following: (1) acting within the scope of the senior officer's authority, engages in corrupt practices on behalf of the corporation; (2) directs the work of another representative of the corporation to engage in corrupt practices on behalf of the corporation; or (3) fails to take reasonable measures to prevent a representative of the corporation from engaging in corrupt practices on behalf of the corporation after becoming aware of the fact that such representative is about to do so. Similarly, the corporation will also be liable under the books and records provision of the CFPOA and the Criminal Code where one of its senior officers engages in, directs, or allows accounting practices designed to hide, disguise, or conceal such corrupt practices.

\section{Directors’ Duties Under CANADian LAW}

It is a well-founded principle that directors are fiduciaries to the corporation. The CBCA has statutorily encoded two directorial duties: first, a fiduciary duty, and second, a duty of care. ${ }^{12}$ Section 122 of the $C B C A$ states:

122(1) Every director and officer of a corporation in exercising their powers and discharging their duties shall

(a) act honestly and in good faith with a view to the best interests of the corporation; and

Supra note 5, s 22.2 [emphasis added].

Ibid.

Ibid.

Supra note 4, s 122(1); ABCA, supra note 4, s 90; OBCA, supra note 4, s 134(1); BCCBA, supra note 4, s 142(1). 
(b) exercise the care, diligence and skill that a reasonably prudent person would exercise in comparable circumstances. $^{13}$

These statutory duties were relatively recently explored in two Supreme Court of Canada cases, Peoples Department Stores Inc. (Trustee of) v. Wise ${ }^{14}$ and BCE. ${ }^{15}$

In Peoples, the trustee in bankruptcy brought an action against the Wise brothers, qua directors of Peoples Department Store, arguing that the Wise brothers had favoured the interests of Wise to the detriment of Peoples' creditors. ${ }^{16}$ Wise had acquired Peoples and, as part of the process, both stores began operating jointly..$^{17}$ Each firm had been experiencing financial difficulties, and in an effort to alleviate problems with inventory and bookkeeping, the Wise brothers implemented a joint inventory procurement policy whereby Peoples would make all the inventory purchases from North American suppliers and Wise would make all inventory purchases from overseas suppliers. ${ }^{18}$ This inventory procurement policy resulted in a significant trade credit being extended from Peoples to Wise. ${ }^{19}$ The financial issues were not resolved and bankruptcy proceedings were initiated against both Peoples and Wise. ${ }^{20}$

In deciding the case, the Supreme Court first clarified that the two duties embodied in section 122 of the CBCA are distinct and separate duties. ${ }^{21}$ Pursuant to section 122(1)(a), directors have a "statutory fiduciary duty," which is "better described as the duty of loyalty,"” to act in the best interests of the corporation. ${ }^{22}$ This requires that directors "act honestly and in good faith vis-à-vis the corporation," that directors "manage the assets of the corporation in pursuit of the realization of the objects of the corporation," that directors "avoid conflicts of interest with the corporation," and that directors "serve the corporation selflessly, honestly and loyally."23

The Supreme Court also clarified that, pursuant to section 122(1)(b), directors additionally owe a duty of care to the corporation, and that this "imposes a legal obligation upon directors ... to be diligent in supervising and managing the corporation's affairs." ${ }^{24}$ In particular, the Court stated that directors are not in breach of their duty of care if they act "prudently and on a reasonably informed basis." 25 This means making "reasonable business decisions in light of all the circumstances about which the directors ... knew or ought to have known." ${ }^{26}$ The Court outlined that in determining whether this duty of care is met, courts will consider whether the "appropriate degree of prudence and [due] diligence was brought to bear in reaching what is claimed to be a reasonable business decision at the time it was made."27

CBCA, ibid, s 122(1).

Peoples Department Stores Inc (Trustee of) v Wise, 2004 SCC 68, [2004] 3 SCR 461 [Peoples].

Supra note 4.

Peoples, supra note 14 at para 25.

Ibid at paras 13-16.

Ibid at para 17.

Ibid at paras 18-20.

Ibid at para 23.

Ibid at paras 32-33.

Ibid at para 32.

Ibid at para 35. The Court further emphasized that it is "settled law" that the fiduciary duty owed by directors imposes "strict obligations" (at para 38).

Ibid at para 32.

Ibid at para 67.

Ibid.

Ibid. 
Importantly, the Court further held that the "establishment of good corporate governance rules should be a shield that protects directors from allegations that they have breached their duty of care." 28

In analyzing whether the Wise brothers had breached their section 122(1)(a) fiduciary duty, the Court stated that the fact that the trial judge had found that there had been no fraud or dishonesty on the part of the Wise brothers in implementing the inventory procurement policy was sufficient to preclude a finding of a breach of their fiduciary duties. ${ }^{29}$ Stated differently, the Court implied that, absent "evidence of a personal interest or improper purpose in the new policy," and in the face of evidence of a "desire" to improve the circumstances of the subject corporation, a breach of the "statutory fiduciary duty," that is, the "duty of loyalty," cannot be sustained. ${ }^{30}$ In analyzing whether the Wise brothers had breached their section 122(1)(b) duty of care, the Court simply held that the procurement policy "was a reasonable business decision that was made with a view to rectifying a serious and urgent business problem in which no solution may have been possible.”31

In $B C E$, a group of debenture holders brought an action for an oppression remedy and alleged that a plan of arrangement approved by BCE was not fair and reasonable as it required the corporation to take on a significant amount of debt which diminished the investment grade trading value of the debentures. ${ }^{32}$ In assessing the claim, the Supreme Court analyzed the directors' fiduciary duties under section 122(1)(a) of the CBCA. The Court stated that the fiduciary duty of directors is a "broad, contextual concept" that "looks to the long-term interests of the corporation." ${ }^{33}$ It underscored that, at a minimum, the fiduciary duty requires directors to "ensure that the corporation meets its statutory obligations." ${ }^{34}$ The Court also stated that, "depending on the context, there may also be other consequences ... directors must look to what is in the best interest of the corporation." 35 No consideration of the scope or substance of the duty of care under section 122(1)(b) occurred as no claim against the directors was made in this respect. ${ }^{36}$

\section{Relevant United States Case LaW}

Although no Canadian cases have examined the application of directors' fiduciary duties and duties of care in the context of CFPOA compliance, a number of US decisions have considered these questions in very similar circumstances. This includes In Re Caremark International Inc., ${ }^{37}$ Stone v. Ritter,${ }^{38}$ and In Re The Dow Chemical Company, ${ }^{39}$ each of these Delaware cases involving shareholder derivative actions instituted by shareholders against

Ibid at para 64 .

Ibid at para 40 .

Ibid at para 41.

Ibid at para 68 .

BCE, supra note 4 at para 4.

Ibid at para 38.

Ibid.

Ibid.

Ibid at para 36.

In re Caremark International Inc, 698 A (2d) 959 (Del Ch 1996) [Caremark].

Stone v Ritter, 911 A (2d) 362 (Del Sup Ct 2006) [Stone].

In re The Dow Chemical Company Derivative Litigation, CA No 4349-CC (Del Ch 2010) (Chancellor Chandler) [Dow]. 
the directors of corporations where the corporations suffered penalties, financial losses, and reputational damage following the failure of corporate monitoring and compliance systems. ${ }^{40}$

\section{A. IN RE CAREMARK INTERNATIONAL INC.}

In Caremark, a derivative action was brought in the Court of Chancery of Delaware claiming that Caremark International Inc.'s (Caremark) board of directors had breached their fiduciary duties to the company in connection with violations by Caremark employees of laws prohibiting bribery, including kickbacks from health care providers or medical and pharmaceutical companies in return for service and products referrals. ${ }^{41}$ Following settlement negotiations and a guilty plea, Caremark paid criminal and civil penalties totalling approximately $\$ 250$ million. ${ }^{42}$ The derivative action was brought to recover Caremark’s losses from the board of directors. ${ }^{43}$

To prevent violations of the anti-referral law, entitled the Anti-Referral Payments Law (ARPL), ${ }^{44}$ Caremark had devised an internal "Guide to Contractual Relationships” intended to govern its employees when entering into contracts with health care providers. ${ }^{45}$ While Caremark's counsel had advised its directors that their contracts were not in breach of the ARPL, Caremark had also been advised that uncertainty remained regarding the correct legal interpretation of the contracts in issue. ${ }^{46}$ Following the initiation of an investigation of Caremark and its predecessor entities by the United States Department of Health and Human Services Office of the Inspector General in respect of suspected ARPL violations, Caremark took additional steps in an effort to assure ARPL compliance. ${ }^{47}$ This initially included publishing a revised version of its internal ARPL guide, instituting an internal policy requiring the approval of each contractual relationship entered into with a physician by a regional zone "president," the conduct of an audit by an external auditor, and the adoption by the company's Audit \& Ethics Committee of a "new internal audit charter requiring a comprehensive review of compliance policies and the compilation of an employee ethics

A number of other derivative shareholder actions have been brought in the context of liability incurred by US companies under the Foreign Corrupt Practices Act, 15 USC § 78dd-1 [FCPA]. However, to the knowledge of the author, none of these have proceeded to material judicial determination prior to publication. These include a derivative shareholder action filed against the eight directors of Pride International Inc following the incursion by that company of approximately US \$56.2 million in liability under the FCPA (Mike Kohler, "Pride International Acquiring a Deferred Prosecution Agreement” (15 February, 2011), online: FCPAProfessor <http://www.fcpprofessor.com/category/pride-international >). The claim alleges, amongst other things, breaches of fiduciary duty resulting from a "lack of internal controls that permitted [Pride] to engage in years of systemic violations of the [FCPA].” See Ferguson $v$ Pride International, Inc, Case No 2010-23805 (281st Dist Ct, Harris County, Tex filed 15 April 2010) at paras 2, 3. Other examples include those derivative actions filed against the directors of FARO Technologies, Inc and Baker Hughes, Inc. See Gibson Dunn Publications, "2009 Mid-Year FCPA Update” (7 July 2009), online: Gibson Dunn Publications <http://www.gibsondunn.com/publications/ pages/2009Mid-YearfcpaClientAlert.aspx> . See also Lawrence J Trautman \& Kara Altenbaumer-Price, "The Foreign Corrupt Practices Act: Minefield for Directors" (2011) 6:1 Virginia Law \& Business Review 145 at $174-76$.

Caremark, supra note 37 at 960-62.

Ibid at $965-66$.

Ibid at 964.

Anti-Referral Payments Act, § 42 USC § 1320a-7b. See also Caremark, supra note 37 at 961-62.

Caremark, ibid at 962.

Ibid at 962-63. Caremark had a practice of entering into contracts for services (e.g. consultation agreements and research grants) with physicians, at least some of whom prescribed or recommended services or services provided by Caremark to Medicare recipients and other patients. As noted by the Court of Chancery, while such payments were not prohibited by the ARPL, "they obviously raised a possibility of unlawful 'kickbacks"” (ibid at 961). 
handbooks concerning such policies."48 This compliance effort later also included "new policies requiring local branch managers to secure home office approval for all disbursements under agreements with health care providers and to certify compliance with the ethics program" as well as the appointment of Caremark's chief financial officer to serve as the company's compliance officer. ${ }^{49}$

Caremark's board of directors was kept generally apprised of these and other developments over the course of the ARPL investigation. ${ }^{50}$ Management had reported that the Company's sales force was receiving regular training regarding the ARPL and the appropriate use of Caremark's standard contracts and that such contracts had been approved by in-house counsel. ${ }^{51}$ The board had also specifically approved Caremark's new ethics manual expressly prohibiting payments in exchange for referrals and implementing "whistleblower" provisions requiring all employees to report unlawful conduct to a confidential toll-free hotline. ${ }^{52}$

The Court of Chancery began its analysis by stating that director liability for "a breach of the duty to exercise appropriate attention may, in theory, arise in two distinct contexts."53 First, it may arise from a board decision that results in a loss because the decision was "ill advised or negligent." 54 Secondly, the Court stated that director liability to the corporation for a financial loss may arise from "an unconsidered failure of the board to act in circumstances in which due attention would, arguably, have prevented the loss." 55

In respect of the former, the Court referenced the "business judgment rule" 56 in finding that a director will not be liable where the director had tried in good faith to make an informed decision and exercise sound judgment. ${ }^{57}$ In respect of the latter, that is, director liability for "unconsidered inaction" or for "failure to monitor," the Court performed a more expansive scrutiny. ${ }^{58}$ The Court first acknowledged that:

\footnotetext{
Most of the decisions that a corporation, acting through its human agents, makes are, of course, not the subject of director attention. Legally, the board itself will be required only to authorize the most significant corporate acts or transactions: mergers, changes in capital structure, fundamental changes in business, appointment and compensation of the CEO, etc. ${ }^{59}$
}

However, also recognizing that "ordinary business decisions that are made by officers and employees deeper in the interior of the organization can ... vitally affect the welfare of the corporation and the ability to achieve its various strategic and financial goals," the Court found that this reality raises the question of a board's "responsibility with respect to the

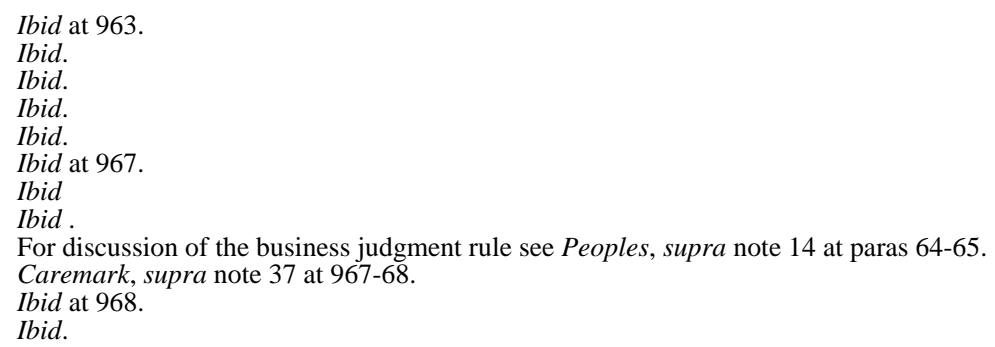


organization and monitoring of the enterprise to assure that the corporation functions within the law to achieve its purposes." 60

An examination of relevant historical precedent followed. This focused on consideration of Graham v. Allis-Chalmers, ${ }^{61}$ a 1963 decision which the Court interpreted to stand for the proposition that "absent grounds to suspect deception, neither corporate boards nor senior officers can be charged with wrongdoing simply for assuming the integrity of employees and the honesty of their dealings on the company's behalf."62 However, following review of more recent case law highlighting the "seriousness with which ... corporation law views the role of the corporate board," 63 as well as the "elementary fact that relevant and timely information is an essential predicate for satisfaction of the board's supervisory and monitoring role," 64 the Court proceeded to clarify that

it would ... be a mistake to conclude ... that corporate boards may satisfy their obligation to be reasonably informed concerning the corporation ... without assuring themselves that information and reporting systems exist in the organization that are reasonably designed to provide to senior management and to the board itself timely, accurate information sufficient to allow management and the board, each within its scope, to reach informed judgments concerning both the corporation's compliance with law and its business performance. ${ }^{65}$

\section{Expanding on this determination, the Court explained that:}

Obviously the level of detail that is appropriate for such an information system is a question of business judgment. And obviously too, no rationally designed information and reporting system will remove the possibility that the corporation will violate laws or regulations, or that senior officers or directors may nevertheless sometimes be misled or otherwise fail reasonably to detect acts material to the corporation's compliance with the law. But it is important that the board exercise a good faith judgment that the corporation's information and reporting system is in concept and design adequate to assure the board that appropriate information will come to its attention in a timely manner as a matter of ordinary operations, so that it may satisfy its responsibility.

Thus, I am of a view that a director's obligation includes a duty to attempt in good faith to assure that a corporate information and reporting system, which the board concludes is adequate, exists, and that failure to do so under some circumstances may, in theory at least, render a director liable for losses caused by noncompliance with applicable legal standards. ${ }^{66}$

Graham v Allis-Chalmers Manufacturing Company, 188 A (2d) 125 (Del Sup Ct 1963) [Graham]. Caremark, supra note 37 at 969 . Graham, ibid, addressed the question of potential liability of board members for losses experienced by the corporation as a result of the corporation having violated US antitrust laws. As acknowledged by the Court in Caremark, there was no claim in Graham that the directors knew about the behaviour of subordinate employees of the corporation that had resulted in the liability but that, as in Caremark, the claim asserted that the directors ought to have known of it and if they had known they would have been under a duty to bring the corporation into compliance with the law and thus save the corporation from the loss. The Caremark Court referenced with approval the finding of the Graham Court that "absent cause for suspicion there is no duty upon the directors to install and operate a corporate system of espionage to ferret out wrongdoing which they have no reason to suspect exists" (at para 32).

Caremark, ibid at 971, referring to Smith $v$ Van Gorkom, 488 A (2d) 858 (Del Sup Ct 1985); QVC v Paramount Communications, 637 A (2d) 34 (Del Sup Ct 1993).

64
Caremark, ibid at 970.

Ibid.

Ibid. 
That said, the Court clarified that "where a claim of directorial liability for corporate losses is predicated upon ignorance of liability creating activities within the corporation," in the Court's opinion "only a sustained or systemic failure of the board to exercise oversight — such as an utter failure to attempt to assure a reasonable information and reporting system exists - will establish the lack of good faith that is a necessary condition to liability" and that such a test of liability "is quite high." 67

Turning to the case at hand, the Court held that the "record supplies essentially no evidence that the director defendants were guilty of a sustained failure to exercise their oversight function" and that, to the contrary, Caremark's "information systems appear to have represented a good faith attempt to be informed of relevant facts." ${ }^{\circ 8}$ While the liability incurred by Caremark was "huge," the Court held that "[i]f the directors did not know [about] the specifics of the activities that lead to the indictments, they cannot be faulted," including because the record did not "support the conclusion that the defendants either lacked good faith in the exercise of their monitoring responsibilities or conscientiously permitted a known violation of law by the corporation to occur." 69

\section{B. Stone V. RitTer AND IN RE Dow}

Caremark is considered a milestone in the evolution of directors' duties in the US and the decision rattled boards across the country. In particular, as precedent for the position that the "failure of a board of directors to ensure that its company has adequate corporate compliance information and reporting systems in place could 'render a director liable for losses caused by non-compliance with the applicable standards" ",70 the decision "struck fear in directors as it warned that, in the wake of misconduct, they could be held personally liable for corporate systems failures." ${ }^{71}$ However, the principles articulated by Caremark have since been tempered by Stone and Dow giving American directors "comfort that they would not simply be held liable whenever substantial losses occurred at companies for which they had director oversight roles." 72

In Stone, a derivative action was brought before the Supreme Court of Delaware against the president and former directors of AmSouth Bancorporation after the company paid \$40 million in fines and $\$ 10$ million in penalties for the failure of bank employees to file "Suspicious Activity Reports" as required by the Bank Secrecy Act and various anti-money laundering regulations. ${ }^{73}$ This followed examinations into AmSouth's compliance with its reporting obligations which had their genesis in government investigations into an unlawful "Ponzi" scheme orchestrated by an attorney and an investment advisor, who, together,

Ibid at 971. The Court also stated that there are "good policy reasons" for it being "difficult to charge directors with responsibility for corporate losses for an alleged breach of care, where there is no conflict of interest or no facts suggesting suspect motivation" (ibid at 967, referring to Gagliardi v TriFoods International, Inc, 683 A (2d) 1049 (Del Ch 1996)).

Ibid at 971 [footnotes omitted].

Ibid at 971-72.

Robert W Tarun, The Foreign Corrupt Practices Act Handbook - A Practical Guide for Multinational General Counsel, Transactional Lawyers and White Collar Criminal Practitioners (American Bar Association, 2012) 67, citing Caremark, supra note 37.

Ibid at 67.

Ibid at 68.

Stone, supra note 38 at 365. 
became the subject of several civil actions brought by defrauded investors in Tennessee and Mississippi, as well as a federal grand jury investigation. ${ }^{74}$

The Stone Court began its analysis by approving the Caremark interpretation of Graham and by emphasizing that "only a sustained or systematic failure of the board to exercise oversight - such as an utter failure to attempt to assure a reasonable information and reporting system exists - will establish the lack of good faith that is a necessary condition to liability." 75 The Stone Court further clarified that the "phraseology used in Caremark ... describing a lack of good faith as a 'necessary condition to liability' is deliberate" as a "showing of bad faith conduct ... is essential to establish director oversight liability." "T6 The Court then summarized Caremark by stating that it articulates "the necessary conditions predicate for director oversight liability,” being that “(a) the directors utterly failed to implement any reporting or information systems or controls; or (b) having implemented such a system or controls, consciously failed to monitor or oversee its operations thus disabling themselves from being informed of risks or problems requiring their attention.”77

The Stone Court identified no failure of the directors of AmSouth to satisfy this standard in the circumstances at hand. ${ }^{78}$ It highlighted that an external auditor's report had found that AmSouth's board had dedicated "considerable resources" to the relevant compliance program and that the board had instituted "numerous procedures and systems to attempt to ensure compliance."79 The Court noted that AmSouth’s directors had "not only discharged their oversight responsibility to establish an information and reporting system," but had also ensured that the system was "designed to permit the directors to periodically monitor" AmSouth's compliance with the regulations at issue..$^{80}$ The Court highlighted that the board's Audit and Community Responsibility Committee oversaw the compliance program on a quarterly basis, that the board was presented with compliance training information annually, and that the board delegated to specific departments and employees responsibility for filing the "suspicious activity reports," the performance of which the board oversaw by relying on periodic reports. $^{81}$

In sum, the Stone Court held that "[a]though there ultimately may have been failures by employees to report deficiencies to the [b]oard, there is no basis for an oversight claim seeking to hold the directors personally liable for such failures by the employees." 2 Furthermore, in so ruling the Court alleviated certain concerns raised by Caremark in stating that:

With the benefit of hindsight, the plaintiffs' complaint seeks to equate a bad outcome with bad faith. The lacuna in the plaintiffs' argument is a failure to recognize that the directors' good faith exercise of oversight

Ibid at 365-66.

Ibid at 368-69.

Ibid at 369-70, referring also to In re Walt Disney Derivative Litigation, 906 A (2d) 27 (Del Sup Ct 2006) [Walt Disney].

Stone, ibid at 370, referring also to Walt Disney, ibid, and Guttman v Huang, 823 A (2d) 492 (Del Ch 2003) [Guttman].

Stone, ibid at 372-73.

Ibid at 371.

Ibid at 371-72.

Ibid at 371-73.

Ibid at 373 . 
responsibility may not invariably prevent employees from violating criminal laws, or from causing the corporation to incur significant financial liability, or both, as occurred in Graham, Caremark and this very case. In the absence of red flags, good faith in the context of oversight must be measured by the directors' actions "to assure a reasonable information and reporting system exists" and not by second-guessing after the occurrence of employee conduct that results in an unintended adverse outcome. ${ }^{83}$

In Dow, a derivative action was brought in the Court of Chancery based, amongst other things, based on the failure of Dow Chemical Company to complete a joint venture with Kuwait's Petrochemicals Industries Company. ${ }^{84}$ The Supreme Council of Kuwait initially approved the transaction but rescinded this approval not long after, unofficially, on grounds related to unacceptable "external interference" and the "politicizing" of the country's oil industry, as well as allegations of "profiteering" and the acceptance by oil executives of inappropriate commissions. ${ }^{85}$ Shareholders brought the derivative action alleging that the directors of Dow breached their fiduciary duties to the company on a number of fronts, including by failing to detect and prevent the bribery of Kuwaiti public officials in connection with the joint venture. ${ }^{86}$

The Court in Dow began by stating that, in order to be successful in a claim based on oversight liability, the plaintiffs must "demonstrate that the defendant directors acted in bad faith and consciously disregarded their fiduciary duties and thus face a 'substantial likelihood' of liability for the alleged bribery." ${ }^{87}$ Referring to the 2009 decision in In re Citigroup Inc., ${ }^{88}$ the Court then held that "to establish oversight liability a plaintiff must show that the directors knew they were not discharging their fiduciary obligations or that the directors demonstrated a conscious disregard for their responsibilities such as by failing to act in the face of a known duty to act." ${ }^{89}$ The Court further highlighted, in language now becoming familiar, that this "test is 'rooted in concepts of bad faith; indeed, a showing of bad faith is a necessary condition to director oversight liability.' Only an 'utter failure' will satisfy a showing of bad faith." 90 The Court also rejected as "simply too attenuated" the plaintiffs' assertion that, because Dow had paid fines to the SEC in 2007 in connection with certain of its operations in India, the board "should have suspected similar conduct" in its other overseas operations regardless of the different country, the different nature of the transaction and industry, and the different members of management involved. ${ }^{91}$ The Dow Court therefore held that, the plaintiffs having failed to establish facts that the Dow board had knowledge of bribery, any reason to suspect bribery, or to suggest that the board had "utterly failed" to supervise the company's employees or act with bad faith, there existed no basis upon which to find that the defendant directors consciously disregarded their duty to supervise against bribery. ${ }^{92}$

Ibid.

Dow, supra note 39 at 1-2, 6.

Ibid at $11-14,16$.

Ibid at $1-2$.

Ibid at 16,44

In re Citigroup Inc Shareholder Derivative Litigation, 964 A (2d) 106 (Del Ch 2009) [Citigroup].

Dow, supra note 39 at 44-45, referring to Citigroup, ibid.

Dow, ibid at 45, referring to Citigroup, ibid, and Lyondell Chemical Company v Ryan, 970 A (2d) 235

(Del Sup Ct 2009).

Dow, ibid at 48-49.

Ibid at 49. In this regard, the Court in Dow also highlighted that the Dow Board had set up policies to prevent bribery and other improper dealings with third parties and that the Dow Code of Ethics expressly prohibited bribery. 


\section{DIRECTORS' DUTIES AND CORPORATE Corruption of Foreign PUblic OfFicials ACt Violations}

While no Canadian court has yet ruled on the circumstances in which the director of a Canadian corporation will have breached his or her director's duties in connection with the incursion by the corporation of criminal liability under the CFPOA, reflection on the principles espoused in Peoples and BCE complemented by consideration of the pronouncements of the courts in Caremark, Stone, and Dow illustrate where such lines may begin to be drawn. ${ }^{93}$

First, pursuant to Peoples and BCE, absent a finding of fraud, dishonesty, or a conflict of interest, it will likely be difficult to establish that a director has breached his or her fiduciary duty in connection with a violation of the CFPOA by the corporation. Therefore, where a director has not deceived or otherwise misled the corporation regarding the CFPOA compliance matter, including, for example, by purposefully omitting to disclose identified compliance risks out of self-interest that a particular transaction proceed, the director will likely bear no liability further to the director's fiduciary duty in respect of any resulting CFPOA violation. Conversely, where the director deceives or otherwise misleads the corporation regarding CFPOA compliance matters, including, for example, by advocating the engagement of a particular third party agent or consultant the director knows will pay a bribe to a foreign public official (and from whom the director will also receive a kickback), the director will likely bear liability under the director's fiduciary duty in connection with the resulting CFPOA violation for failing to act in good faith in the best interests of the corporation. $^{94}$

Secondly, pursuant to Peoples, courts will consider a number of factors in determining whether a director has met his or her duty of care in connection with a violation of the CFPOA by the corporation. This includes considering whether the director was diligent in supervising the corporation's related affairs, whether the director acted prudently and on a reasonably informed basis in respect of the matter, whether the director made reasonable decisions in respect of the matter in light of all the circumstances about which the director knew or ought to have known, and whether the director brought to bear an appropriate degree of prudence and due diligence in making decisions related to the matter. This will also include considering the director's role in establishing good corporate governance rules related to the matter. Therefore, the greater the degree to which a director was diligent in considering and managing anti-corruption risks, acted prudently and in a reasonably informed basis regarding anti-corruption risks, considered all relevant circumstances in making decisions related to anti-corruption risks, and was cautious and advocated judicious due diligence regarding anti-corruption risks, the more difficult it will be to argue that the director breached his or her duty of care in respect of a violation of the CFPOA by the corporation. Conversely, where the director fails markedly in these responsibilities, including

93 Note that certain procedural obstacles are presented by shareholder derivative suits, the discussion of which are beyond the scope of this article. For a discussion of these procedural difficulties in the context of US law, see Amy Deen Westbrook, “Double Trouble: Collateral Shareholder Litigation Following Foreign Corrupt Practices Act Investigations” (2012) 73:5 Ohio State Law Journal 1217 at 1229-32.

94 Consider, also, possible conflicts of interest arising where the director has significant shareholdings in the corporation. 
by failing to ensure the development of sufficient good governance rules addressing anticorruption risks, the less challenging this task will be.

Drawing from the facts canvassed by Caremark, Stone, and Dow provides further colour regarding how a director's duty of care may be satisfied in the context of anti-corruption risk. As explored in Caremark, Canadian directors should consider the following: (1) devising internal codes targeted specifically at potentially high risk situations and high risk relationships; (2) seeking legal advice regarding difficult legal interpretation and analysis regarding statutory obligations or potentially high risk contractual relationships; (3) taking additional risk mitigation steps where problematic circumstances are identified, including reevaluating and revising compliance policies; (4) requiring the approval of designated senior officials of potentially high risk transactions; (5) enlisting the services of third party auditors where problematic events or information are identified; (6) implementing rigorous internal auditing requirements; (7) requiring that designated classes of employees and representatives periodically certify compliance with risk mitigation policies and procedures; (8) the appointment of senior executive offers and executive committees to oversee compliance monitoring and enforcement; (9) the implementation of "whistleblower" provisions requiring all employees and representatives to report unlawful or otherwise inappropriate conduct; and (10) requiring regular training of employees and representatives regarding compliance and risk mitigation policies and procedures. Pursuant to Caremark and Stone, Canadian directors should also consider providing: (1) that all anti-corruption policies and procedures are designed to permit the directors to periodically review their corporation's compliance performance; and (2) that information and reporting systems function to provide the board with timely and accurate information sufficient to allow the board to reach informed judgments regarding the corporation's anti-corruption risk exposure and compliance on an ongoing basis.

That said, Canadian companies, courts, and directors should be cautious when consulting these and related US cases for guidance on the appropriate exercise of director responsibility in the face of anti-corruption risk. The Supreme Court stressed in Peoples that the two duties embodied in section 122(1) of the CBCA are distinct and separate obligations. ${ }^{95}$ The courts in Caremark, Stone, and Dow do not abide by such a firm division. ${ }^{96}$ The Court in Caremark begins its analysis by examining the content of a director's duty to exercise due and “appropriate attention." ${ }^{\text {"97 }}$ However, Caremark, Stone, and Dow each proceed from this foundation to simultaneously require that bad faith be established alongside a failure to exercise due attention. As held in Stone:

[The] imposition of liability requires a showing that the directors knew that they were not discharging their fiduciary obligations. Where directors fail to act in the face of a known duty to act, thereby demonstrating a conscious disregard for their responsibilities, they breach their duty of loyalty by failing to discharge that fiduciary obligation in good faith. ${ }^{98}$

$95 \quad$ Peoples, supra note 14 at paras 32-33 [emphasis added].

96 See Leo E Strine Jr et al, "Loyalty’s Core Demand: The Defining Role of Good Faith in Corporation Law,” 98 Geo LJ 629 at 636 discussing fiduciaries duties under the law of Delaware and stating that every fiduciary act implicates the duty of loyalty and thus "the duty of care can properly be regarded as subsidiary requirement of the duty of loyalty."

$97 \quad$ Caremark, supra note 37 at 967.

$98 \quad$ Stone, supra note 38 at 370 [emphasis added]. 
Similarly, as held in Dow:

To establish oversight liability, a plaintiff must show that the directors knew they were not discharging their fiduciary obligations or that the directors demonstrated a conscious disregard for their responsibilities such by failing to act in the face of a known duty to act ... [this] test is 'rooted in concepts of bad faith; indeed, a showing of bad faith is a necessary condition to director oversight liability.' Only an 'utter failure' will satisfy a showing of bad faith. ${ }^{99}$

Pursuant to Peoples, it does not appear that Canadian courts would apply such a hybrid standard. Rather, the determination of the Supreme Court in Peoples that the "establishment of good corporate governance rules should be a shield that protects directors from allegations that they have breached their duty of care" ${ }^{100}$ creates the risk that Canadian courts may look unfavourably at one or more directors that failed to ensure the implementation of adequate anti-corruption policies and procedures in light of the company's exposure to significant anticorruption risk without also requiring bad faith on the part of the director in connection with such failure.

Towards this end, when considering how to fulfill their duty of care regarding the implementation and enforcement of anti-corruption policies and procedures, Canadian directors should also weigh the prescriptions of the "business judgment rule," namely that principle which "shield[s] from court intervention business decisions which have been made honestly, prudently, in good faith and on reasonable grounds." 101 The parameters of the business judgment rule were recently reviewed by the Supreme Court of Canada in Kerr v. Danier Leather, ${ }^{102}$ which approved the treatment of the rule adopted in Maple Leaf Foods Inc. v. Schneider Corp: ${ }^{103}$

The court looks to see that the directors made a reasonable decision not a perfect decision. Provided the decision taken is within a range of reasonableness, the court ought not to substitute its opinion for that of the board even though subsequent events may have cast doubt on the board's determination. As long as the directors have selected one of several reasonable alternatives, deference is accorded to the board's decision. $^{104}$

That said, while the rule grants to directors certain shelter from the consequences of ultimately ill-fated business decisions, it is important to highlight that the rule also arguably creates a concurrent expectation. Namely, as held by the Court in UPM-Kymmene Corp., “directors are only protected to the extent that their actions actually evidence their business judgment. The principle of deference presupposes that directors are scrupulous in their

Dow, supra note 39 at 44-45 [emphasis added]. See also, Rich ex rel Fuqi Intern, Inc v Yu Kwai Chong, 2013 WL 1914520 (Del Ch 2013) at 12 (holding that Caremark claims are breaches of the duty of loyalty as opposed to care. Thus, in order for a director to be found liable under the Caremark standard, a director must either utterly fail to implement any reporting or information system controls, or, having implemented such controls, consciously fail to monitor or oversee their operation). Peoples, supra note 14 at para 64. CW Shareholdings v WIC Western International (1998), 160 DLR (4th) 131 (Ont Gen Div) at para 57. See also Peoples, ibid, at paras 64-67.

1022007 SCC 44, [2007] 3 SCR 331 [Kerr].

103 (1998), 42 OR (3d) 177 (CA), 44 BLR (2d) 115 [Maple Leaf Foods]. 
deliberations and demonstrate diligence in arriving at decisions.”105 This should include taking "active steps to seek out relevant information" as well as to inform themselves "about both the strengths and weaknesses of available options." 106 This may also include "reasonable efforts to identify the risks to which particular lines of business and significant transactions may expose the corporation, and to make proper provisions for those risks (or to confirm that such provision has been made)." ${ }^{107}$ Directors cannot reasonably be expected to at all times "prevent the malfeasance, misfeasance or nonfeasance of the corporation's employees, or those with whom it deals." 108 However, directors may be expected to "put into place reasonable precautions to deter such improper behaviour and to allow such wrong-doing to be detected when it occurs." 109

\section{DIRECTORS’ DUTIES AND ANTI-CORruption Policies AND Procedures}

In total, the guidance provided by Peoples, BCE, Caremark, Stone, Dow, and other case law and commentary canvassed above can be distilled down to two primary principles. First, protection against potential liability for a failure to satisfy a director's duty of care to a corporation in connection with anti-corruption compliance failures begins with the implementation and enforcement of anti-corruption policies and procedures designed to protect against corrupt practices by the company's officers, employees, and other representatives. Secondly, Canadian directors should then take time to be reasonably involved in the implementation and enforcement of such policies and procedures as appropriate going forward, which may include: (1) through periodic review of the corporation's anti-corruption compliance performance; (2) through timely review of material developments in the corporation's anti-corruption risk exposure or compliance; and (3) through timely, prudent, and proactive response to material developments in the corporation's anti-corruption risk exposure or compliance.

Where, then, should companies and their directors look for guidance regarding the scope and substance of adequate anti-corruption policies and procedures? Fortunately, the trials of Niko Resources and its subsequent Probation Order provide ready and court-sanctioned instruction. Specifically, while the general facts surrounding the Niko Resources cases are now well known, ${ }^{110}$ a closer examination of the Alberta Court of Queen's Bench sentencing

UPM-Kymmene Corp v UPM-Kymmene Miramichi Inc (2002), 214 DLR (4th) 496(ONSC) at para 156. Halsbury's Law of Canada, 1st ed, Lexis Nexis at HBC-229 at 752 [Halsbury's], referring to In Re Pure Resources, Inc Shareholders Litigation, 808 A (2d) 421 (Del Ch 2002) and, generally, Cinerama Inc $v$ Techncolor, Inc, 663 A (2d) 1134 (Del Ch 1994) (affirmed 663 A (2d) 1156 (1995)).

Halsbury's, supra note 106 at 744.

Ibid at 745 .

Ibid, referring to Briggs, Receiver v Spaulding (1891), 141 US 132.

Transcript of Proceedings Taken in the Court of Queen's Bench of Alberta, Calgary Courts Centre, Calgary Alberta, Her Majesty the Queen v Niko Resources Ltd, E-File No.: CCQ11NIKORESOURCES, 24 June 2011 [Niko Resources Order]. On 24 June 2011, Niko pled guilty to a single charge of bribery under the CFPOA related to two incidents that occurred in 2005 following an explosion at its Bangladesh natural gas field. At that time, Niko was also engaged in negotiating a gas pricing contract with the Bangladesh government. Niko’s Bangladesh subsidiary provided a \$190,984 vehicle to the Energy Minister in Bangladesh and paid his travel costs of \$5,000 to attend an Energy Expo in Calgary and for a trip to New York and Chicago to visit family. The Court accepted the sentencing recommendation which included a fine and victim surcharge totalling \$9,499,000 and a Probation Order under which Niko will be subject to Court supervision and regular independent audits to confirm its compliance with the CFPOA. Costs of compliance with the Probation Order will be borne by Niko. 
proceedings and the Agreed Statement of Facts provides helpful insights both into the approach federal authorities are taking to the investigation, prosecution, and penalization of corrupt practices as well as to the preventive steps Canadian companies will be expected (by Crown prosecutors and the RCMP) to take to guard against corrupt practices, including the scope and substance of expected anti-corruption policies and procedures. ${ }^{111}$ The Niko Resources Order is instructive in two main respects in this regard.

First, the anti-corruption policies and procedures imposed by the Court on Niko Resources in the Order going forward are instructive as a list of different CFPOA compliance measures expected to be implemented by Canadian companies. These include among other things:

- An anti-corruption compliance code designed to detect and deter violations of the CFPOA and other applicable anti-corruption laws;

- A system of internal financial and accounting controls and procedures designed to ensure fair and accurate books and records and to guard against manipulation towards corrupt ends;

- The assignment of anti-corruption compliance responsibility to senior corporate officer(s) or executive(s) with direct reporting to independent monitoring bodies, such as internal audit committees, ethics committees, or the board of directors;

- The periodic reviewing, testing, and updating of anti-corruption policies and procedures at least annually;

- The periodic training and annual certification of directors, officers, employees, agents, and business partners;

- The institution of systems for providing anti-corruption guidance and advice both within the company as well as to business partners and third party agents, including confidential reporting of possible contraventions and protection against retaliation for "whistleblowers";

- The practice of (1) swiftly responding to and investigating reports of anti-corruption non-compliance, and (2) taking appropriate action, including disciplinary procedures for identified violations of anti-corruption laws and policies; and

- The institution of due diligence and compliance requirements regarding the engagement, retention, and oversight of agents and business partners, including the documentation of such initial and continuing due diligence as well as all appropriate contractual representations, warranties, covenants, and other rights addressing anticorruption risk, compliance, and oversight. ${ }^{112}$ 111 John W Boscariol, “Anti-Corruption Compliance Message Received? Risk Assessment Is Your Next
Step” (13 August 2012), online: McCarthy Tétrault <http://www.mccarthy.ca/article_detail.aspx? id $=5985$. 
Secondly, the Niko Resources Order implies anti-corruption policies and procedures will be most useful where they are reasonably customized to account for a company's individual circumstances. In other words, although a quick Internet search easily locates many examples of generic anti-corruption compliance programs and training modules, the Niko Resources Order suggests that merely adopting such a standard code may not represent meaningful CFPOA risk mitigation. Rather, the Order stands as precedent that Canadian companies may be expected to conduct an individualized anti-corruption risk assessment of their operations and business relationships and to devise anti-corruption policies and procedures which address identified material risks in a targeted fashion. ${ }^{113}$ Specifically, Niko Resources was instructed to

develop [its anti-corruption] compliance standards and procedures, including internal controls, ethics and compliance programs, on the basis of a risk assessment addressing the individual circumstances of the company, in particular foreign bribery risks facing the company, including, but not limited to, its geographical organization, interactions with various types and levels of government officials, industrial sectors of operation, involvement in joint venture agreements, importance of licenses and permits in the company's operations, degree of governmental oversight and inspection, and volume and importance of goods and personnel clearing through customs and immigration. ${ }^{114}$

Directors of Canadian companies with foreign operations or business partners should consider this advice. ${ }^{115}$ Anti-corruption policies and procedures not reasonably tailored to material risks identified pursuant to a company-wide risk assessment may be of less protective value before the eyes of the courts. ${ }^{116}$ The unconsidered adoption of generic anticorruption policies and procedures may also engender a false sense of compliance confidence while simultaneously overlooking key areas of corrupt practices risk exposure.

Note also the potential prudence of conducting such a review of a corporation's particular circumstances when designing its anti-corruption policies and procedures was recently reinforced by the Alberta Court of Queen's Bench in the second major conviction under the CFPOA, namely that of Griffiths Energy International Inc. on 25 January $2013 .{ }^{117}$ In

Support for this approach can be found in other Canadian jurisprudence. See, for example, the decision of the Court of Appeal of British Columbia in $R v$ Imperial Oil, 2000 BCCA 553, 148 CCC (3d) 367 [Imperial Oil] at para 28: "It is not a good answer for the appellant to say that it had in general a good safety system, that it tested it more frequently than necessary, and that it had a program which would likely have detected the hazard within the near future. Because the appellant did not identify the substance as toxic, it was not a priority within the risk assessment program." See also the advice of the DOJ and the SEC regarding the hallmarks of effective anti-corruption compliance programs; US Department of Justice and the Securities Exchange Commission, A Resource Guide to the U.S. Foreign Corrupt Practices Act, online: US Securities and Exchange Commission <http:/www.sec.gov/spotlight/ fcpa/fcpa-resource-guide.pdf $>$ [FCPA Guide] at 57-62. Niko Resources Order, supra note 110.

115 This analysis is echoed by the UK [Ministry of Justice] which, in its guidance to the Bribery Act, identifies several external and internal exposure issues for consideration during company-specific risk assessment. External risks are categorized into five groups, namely (1) country risk; (2) sectoral risk; (3) transaction risk; (4) business opportunity risk; and (5) business partnership risk. Internal risk considerations include (1) deficiencies in employee training and skills; (2) a culture that rewards excessive risk taking; (3) a lack of clarity in the company's policies; (4) a lack of clear financial controls; and (5) a lack of a clear anti-bribery message from senior management. See The Ministry of Justice, "The Bribery Act 2010: Guidance about procedures which relevant commercial organisations can put into place to prevent persons associated with them from bribing," online: The Ministry of Justice <http:// www.justice.gov.uk/downloads/legislation/bribery-act-2010-guidance.pdf > .

117 For further detail, see section VII below. 
particular, in outlining the mitigating factors to be taken into account in deciding the amount of the fine to be levied against the company, the Crown on more than one occasion highlighted that the company had, upon the discovery of suspected violations of the CFPOA by past management, included the swift implementation and enforcement of a robust set of anti-corruption policies and procedures as part of its suite of corrective measures. ${ }^{118}$

Towards this end, at least another point regarding company-specific foreign corruption risk assessment and the anti-corruption policies and procedures crafted thereafter should be noted, and this is that the more sophisticated an organization is, the more sophisticated Canadian courts may expect the organization's anti-corruption policies and procedures to be. ${ }^{119}$ In Imperial Oil, Imperial was found liable under the British Columbia Waste Management Act and the Fisheries Act in connection with the discharge into Burrard Inlet of certain toxins from its Inco Refinery in 1995. The company maintained a due diligence defence, contending that all reasonable precautions had been taken, but this argument was rejected. ${ }^{120}$ Stated simply, the Court of Appeal held that Imperial: (1) should have been aware of the toxicity of a certain component of the discharged substances; and (2) should have known that its refinery's separation processes were insufficient to filter this toxic component from the discharged substances. ${ }^{121}$ In so holding, the Court repeated the observations of the trial judge that, "[g]iven the evidence of the size of the operations at this refinery, the size of the company as a whole, and the evidence of its ability and willingness to access outside expertise whenever required, the skill level expected of the accused was very high."122 It therefore found that, "given its nature and size," Imperial "had ample expertise available to it" to identify and address the possibility of the toxic discharge prior to its occurrence. ${ }^{123}$

Nonetheless, smaller companies and their directors should not necessarily rely on this precedent as justification for adopting a less robust or more informal approach to anticorruption compliance. The lesson of Imperial Oil is likely not so much that that more may be expected of some entities than of others, but that each Canadian company may be expected to do that reasonably within its means to anticipate and prevent it or its representatives from engaging in corrupt practices. On the other hand, it is only reasonable that Canadian enforcement authorities recognize and appreciate that not all Canadian companies will have the same amount of resources to dedicate to anti-corruption compliance and risk mitigation. This appears to be the case in the US where the DOJ and the SEC have recently stated that "small- and medium-size enterprises likely will have different compliance programs from large multi-national corporations, a fact DOJ and SEC take into account when evaluating companies' compliance programs." ${ }^{24}$ Nor would it be reasonable for Canadian enforcement authorities to view the anti-corruption policies and procedures imposed by the Niko Resources Order as some sort of baseline standard that all other Canadian companies

Her Majesty the Queen and Griffiths International Energy Inc, Agreed Statement of Facts, 14 January 2013 [Griffiths Statement of Facts].

119 Todd L Archibald, Kenneth E Jull \& Kent W Roach, Regulatory and Corporate Liability: From Due Diligence to Risk Management, loose-leaf (Toronto, Canada Law Book, 2004) at ch 17-18.

Imperial Oil, supra note 113 at paras 1-3.

Ibid at paras 9, 11, 15-16, 19, 27-30.

Ibid at para 8.

Ibid at paras 27, 29.

See supra note 113 at 57. 
with foreign operations should meet or exceed in their own compliance efforts. The prescriptions of the Niko Resources Order were drafted with the actions of a past violator of the CFPOA in mind and therefore cannot reasonably be wholesale shifted to the shoulders of peers undeserving of such a burden. So too must the often-times considerable costs of anticorruption compliance be given due regard in calculating reasonable standards of anticorruption compliance efforts.

Notably, Canadian case law appears to support such an approach. For example, in $B C E$ the Supreme Court of Canada held that the substance of a director's duty of care is dependent upon prevailing commercial practice in a particular industry as well as the size, nature, and structure of the corporation. ${ }^{125}$ Further, the Court also noted that directors of small closely held corporations enjoy greater latitude in the application of the duty of care standard than directors of large corporations. ${ }^{126}$ So too do the principles informing the "business judgment rule” support this conclusion. In particular, while a director's duty of care will likely always require the following: (1) that directors be engaged and diligent in analyzing a corporation's anti-corruption risk exposure; and (2) that directors demonstrate thoughtfulness in addressing and mitigating such risk exposure, the "business judgment rule" applicable to such duty of care equally suggests that directors should be afforded discretion to select from more than a single anti-corruption risk mitigation strategy so long as such strategy is reasonable considering (a) the corporation's particular operations and circumstances; (b) the corporation's finances and other resources; and (c) industry best practices (including, at present, the prescriptions of the Court in the Niko Resources Order). ${ }^{127}$

So what does all of this finally mean in the real-world of business and legal practice? Or stated somewhat differently, what is it reasonable for courts and regulators to expect from Canadian directors serving on the board of a corporation faced with anti-corruption risk? Several particularly salient issues are identifiable. The first is that not all anti-corruption risk is equal, and that different degrees of anti-corruption risk mitigation will be warranted in different circumstances. Therefore, less attention to anti-corruption risk mitigation should be expected of the directors of corporations faced with relatively low anti-corruption risk (for example, only 10 percent of its business taking place in high-risk jurisdictions) than is expected of the directors of corporations faced with relatively high anti-corruption risk exposure (for example, 90 percent of its business taking place in high-risk jurisdictions). So too should the actual level of involvement of the directors in the process of anti-corruption risk mitigation be tempered by the realities of the business world and the multiplicity of competing demands on a director's time and capacity.

$B C E$, supra note 4 at paras 73-74 (holding that the substance of the obligations owed by a director to a corporation may vary depending on the size and industry of the corporation of the entity). See also Garage Technology Ventures Canada, SEC Leger, 2012 QCCA 1901, [2012] RJQ 2030 at paras 69-70, holding that the scope of a director's obligations are a function of the nature of the business/company in question and concluding that failure on the part of a Court to consider the nature of a director's business, risks putting disproportionate obligations on the director and thus undermining the very purpose of the CBCA. $B C E$, ibid at paras 73-74.

$127 \quad$ See Maple Leaf Foods, supra note 103 at para 192, where it was held that

[t]he court looks to see that the directors made a reasonable decision not a perfect decision. Provided the decision taken is within a range of reasonableness, the court ought not to substitute its opinion for that of the board even though subsequent events may have cast doubt on the board's determination. As long as the directors have selected one of several reasonable alternatives, deference is accorded to the board's decision. 
It is reasonable to expect that where the corporation is faced with identifiable anticorruption risk of a not insignificant nature that the board of directors will educate itself regarding the scope and substance of anti-corruption law and how it may apply to the corporation's business operations (for example, through a comprehensive presentation to the board by internal or external legal counsel). It is also reasonable to expect that this board dedicate a reasonable amount of time and attention to the design of the corporation's anticorruption policies and procedures, including by ensuring that: (1) they are reasonably customized to the corporation's particular operations and risk exposure; (2) that they include procedures which ensure that material anti-corruption concerns are brought to the attention of the board in a timely manner; (3) the importance of anti-corruption risk identification and compliance is made clear to all employees and personnel (that is, that the right "tone from the top" is established in respect of the importance of the corporation's anti-corruption policies and procedures); and (4) that the implementation and enforcement of the corporation's anti-corruption policies and procedures are delegated to appropriately qualified and experienced individuals (for example, a chief compliance officer).

However, it is unreasonable to expect directors to be "on the ground" or otherwise deeply immersed in the execution of the corporation's anti-corruption policies and programs. It is also unreasonable to expect that anti-corruption risk mitigation be the central or predominant focus of a board, even in the case of a corporation with relatively high anti-corruption risk exposure. Next, subject to adverse compliance developments or the significant expansion of the corporation's sphere of business operations, nor is reasonable to expect the board - once having established appropriate anti-corruption policies, procedures and enforcement systems — to again consider the corporation's anti-corruption compliance going forward outside the periodic (for example, annually) review of anti-corruption audits and reports conducted further to the corporation anti-corruption policies and procedures. The duty of care owed by directors to the corporation is a broad and inclusive duty, and corporations - no matter where they operate - face a multiplicity of risks (legal, financial, commercial and otherwise) which stretch far beyond those related to anti-corruption law and compliance, and all of which require careful consideration by directors. Finally, it is unreasonable to automatically assume that where a corporation attracts anti-corruption liability, such liability can in some manner be attributed to a breach by the directors of their duties to the corporation, however material the liability may be. Serious corrupt practices are inherently committed by dishonest individuals motivated by greed and committed to their pursuit regardless of the law and regardless of the consequences for the corporations they represent. This can often make their schemes impossibly difficult to guard against, no matter how diligent the effort.

\section{DiRECTORS’ DUTIES AND SPECIAL INVESTIGATIONS}

Just as the Niko Resources Order provides useful instruction regarding possible anticorruption policies and procedures to be adopted by Canadian companies, the guilty plea of Griffiths Energy International Inc. on 25 January 2013 provides useful instruction regarding 
possible responses by companies and their boards of directors upon the discovery of proven or suspected past corrupt practices by the company or its representatives. ${ }^{128}$

The conviction of Griffiths Energy centers on a series of consulting services agreements and related transactions between the company, a Calgary-based junior oil and gas exploration company, and foreign consultants at the direction of its previous management. As noted in the Agreed Statement of Facts dated 22 January 2013 submitted by the company and Crown prosecutors to the Queen's Bench of Alberta, starting approximately in early August 2009, certain individuals among the previous management of Griffiths Energy and a number of its founding shareholders began a campaign to develop contracts and arrange meetings with senior political figures in the Republic of Chad in pursuit of certain production sharing contracts in the country, including the Chadian Ambassador to Canada and the country's Minister of Petroleum and Energy. ${ }^{129}$

Shortly thereafter, Griffiths Energy executed a consulting agreement dated 30 August 2009 with an entity entitled Amassade du Tchad LLC, a US incorporated entity wholly owned by the Chadian Ambassador to Canada. ${ }^{130}$ The agreement provided for certain oil and gas advisory services to be provided by the entity to Griffiths Energy and, importantly, provided for a success fee of \$2 million payable to the entity in the event Griffiths Energy was granted the sought-after production sharing contracts before the end of the 2009 calendar year. ${ }^{131}$ The agreement was terminated by Griffiths Energy after the company was advised by legal counsel that it constituted an unlawful benefit to a foreign public official in contravention of the CFPOA. ${ }^{132}$ Nonetheless, Griffiths Energy thereafter entered into a second consulting services agreement dated 15 September 2009 with another US incorporated entity, this time wholly owned by the wife to the Chadian Ambassador to Canada. ${ }^{133}$ The terms of this second contract were largely identical to the first contract and included the same success fee of $\$ 2$ million payable upon the granting of the production sharing contracts to Griffiths Energy. ${ }^{134}$

Following the expiration of its initial term, the second consulting services agreement was renewed by the parties effective 1 January 2011. ${ }^{135}$ Not long after this, and following months of negotiations between Griffiths Energy and Chad, a subsidiary of Griffiths Energy executed a production sharing contract with Chad on 19 January 2011. ${ }^{136}$ The success fee of $\$ 2$ million under the renewed consulting services agreement was thereafter placed into escrow by Griffiths Energy in February 2011 before then being transferred to the entity owned by the

Transcript of Proceedings Taken in the Court of Queen's Bench of Alberta, Judicial Centre of Calgary, Her Majesty the Queen v Griffiths Energy International, E-File No: CCQ13GRIFFITHSENER, 25 January 2013 [Griffiths Conviction]. Griffiths Statement of Facts, supra note 118 at paras 11-14.

Ibid at para 20.

Ibid.

Ibid at para 21.

Ibid at para 22

Ibid at paras 22-24. Note that, contemporaneous with the execution of the second consulting services agreement, Griffiths also granted to the Ambassador's wife 1,600,000 founder shares in the company at a price of 0.001 per share as well as an additional 2,400,000 founder shares at the same price to two individual nominated by the Ambassador's wife, including the wife of the then Deputy Chief of the Chadian Embassy in Washington, DC. 
wife of the Ambassador pursuant to deposit instructions received from the Deputy Chief of the Chadian Embassy in Washington, D.C. ${ }^{137}$

Pursuant to the Agreed Statement of Facts submitted to the Court, Griffiths Energy acknowledged that by entering into the aforementioned consulting services agreements it had violated section 3(1)(b) of the CFPOA by providing direct or indirect benefits to the Ambassador in an attempt to induce the Ambassador to use his position and authority to help steer the government of Chad towards awarding one or more production sharing contracts to the company. ${ }^{138}$ However, the Agreed Statement of Facts and the subsequent Conviction issued by the Court of Queen's Bench also contain an accounting of a number of positive actions taken by the company and its representatives which will be of great value to any Canadian company and its directors which ever find themselves in similar circumstances. In particular, the Griffiths Energy conviction highlights several mitigating actions taken by the company's new management following the discovery of the offending consulting services agreements during due diligence performed in preparation for an initial public offering by the company.

Most importantly for the purposes of this article, such mitigating actions included prompt corrective action taken by Griffiths Energy's management and board of directors, including (1) the creation of a Special Committee comprised of the independent members of Griffiths Energy's board of directors to investigate the company's past activities in Chad; (2) the retention by the Special Committee of specialized and independent external legal counsel; (3) the provision by the Special Committee of a broad mandate to its external legal counsel to conduct a thorough investigation of not only the circumstances surrounding the consulting services agreements and related transactions in question, but also any other activities possibly suggestive of past corrupt practices by the company or its representatives; and (4) that both the Special Committee as well as the remainder of Griffiths Energy's directorship and management kept themselves fully engaged and informed regarding the progress of the special investigation. ${ }^{139}$ In addition, the Court recognized that Griffiths Energy was clearly dedicated to the cause of the Special Committee, including by (1) incurring related legal and accounting costs of approximately CDN\$5 million; and (2) committing hundreds of management hours to further support the Special Investigation. ${ }^{140}$ The Court of course also acknowledged the importance of Griffiths Energy's decision to voluntarily self-report the findings of the special investigation to the RCMP and Crown Prosecutors as well as the company's continued cooperation with regulatory officials thereafter. ${ }^{141}$

Towards this end, while the Court of Queen's Bench discussed these actions of Griffiths Energy, its board of directors and its new management largely in the context of mitigating behaviour relevant to the Court's sentencing of the company, ${ }^{142}$ it is important to appreciate that the actions taken by Griffiths Energy's directors and the Special Committee simultaneously represent the type of response arguably required by the company's directors

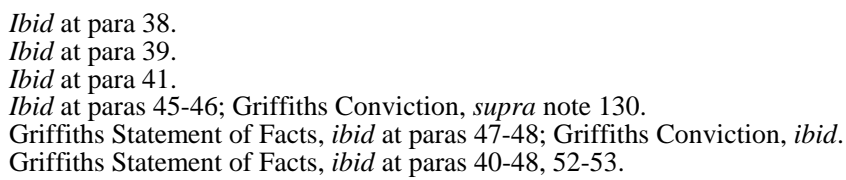


to have complied with their duty of care to the company in the circumstances. Stated differently, had the directors of Griffiths not responded as they did, it is arguable that they may have failed to meet their duty of care to the company (and have potentially exposed themselves to attendant civil liability to the company’s shareholders as a result).

As non-compliance with anti-corruption law attracts criminal liability as well as potential regulatory intervention in a corporation's affairs, it is likely only prudent that an internal investigation into suspected or proven material corrupt practices bear the authority and imprint of a special committee. ${ }^{143}$ Furthermore, once this avenue is agreed upon, case law suggests that the corporation's directors ensure that the special committee is composed of: (1) independent, outside directors free from conflict with management; and (2) directors of appropriate experience, qualification, and availability to conduct the investigation. ${ }^{144}$ This obligation also likely includes the responsibility to ensure that the mandate and authority of the committee is sufficient to thoroughly scrutinize the corporation's anti-corruption compliance. Case law also suggests that those directors appointed to the special committee should be careful to fully appreciate the importance and the scope and substance of their responsibilities in the circumstances. ${ }^{145}$ This likely includes ensuring: (1) that they obtain adequate information and advice; and (2) that they give such information and advice the attention and consideration necessary to arrive at a reasoned judgment. This will also likely include retaining appropriately qualified specialists, including, for example, forensic accountants. ${ }^{146}$ Lastly, this will also likely include retaining external legal counsel that is free from conflicts of interest related to, amongst other things: (1) the possible investigation of senior officers or management; or (2) previous transactions or legal advice in any manner related to the possible anti-corruption compliance failures being investigated. ${ }^{147}$

Where a special committee conducts an investigation into suspected or proven corrupt practices by a company or its representatives in accordance with these principles, the remainder of the board will be in a position to rely on the committee's findings and recommendations. ${ }^{148}$ That said, the remainder of the board should be careful not to rely on the investigation conducted by the special committee, but should meet their own duty of care in satisfying themselves that the special committee exercised prudence, diligence and reasonable judgment in its efforts. Of course, the directors of the company should also be

See CW Shareholdings Inc v WIC Western International Communications Ltd (1998), 39 OR (3d) 755 at para 44 where the Court stated that "[r]etaining independent legal and financial advisors, and the establishment of independent or special directors' committees to assess and respond to the hostile bid, are the classic mechanisms to which boards of directors have traditionally resorted in order to cope with their difficult duties and conflicting position.” See also Carol Hansell \& David Brown, "Board Investigations of Corporate Conduct" (23 July 2008), online: Davies <http://www.dwpv.com/ en/Resources/Publications/2008/Article-Board-Investigations-of-Corporate-Conduct>; Torys LLP, "Responsibilities of Directors in Canada: A Business Law Guide,” online: Torys <http://www.torys. com/Publications/Documents/Publication\%20PDFs/Responsibilities_of_Directors_2009.pdf> at 27. Re YBM Magnex International Inc (2003), 26 OSCB 5285 at paras 197, 240, 246-50, 273 [YBM Magnex]. Contrast with In re Plains Exploration \& Production Co Stockholder Litigation, 2013 WL 1909124, at 1 (Del Ch 9 May 2013), which is a Delaware Chancery Court decision describing circumstances in which a board in its normal composition was sufficiently independent and that, as a result, a special committee was not necessary in the context of a merger discussion.

YBM Magnex, ibid at para 185.

Ibid at paras 182, 286, 289, referring to Soper v Canada, [1998] 1 FC 124 (CA), 149 DLR (4th) 297 at paras 26, 53 [Soper].

YBM Magnex, ibid at para 186, referring to Re Standard Trustco Ltd (1992), 15 OSCB 4322 at 4364-365 [Standard Trustco] and also at para 254, referring to Blair v Consolidated Enfield Corp (1993), 15 OR (3d) 783 at 796-801.

YBM Magnex, ibid at para 253. 
careful to ensure that both they and the company continue to meet their obligations further to the special investigation and the findings of the Special Committee, including, in particular, in connection with any applicable disclosure requirements under securities laws. ${ }^{149}$

As is well known, depending on the circumstances, reporting issuers subject to disclosure requirements under Canadian securities laws are obligated, inter alia, to disclose to the market "material facts" related to the issuer's business or assets or "material changes" to the issuer's business or assets. Therefore, given that a special investigation of suspected or proven corrupt practices can lead to the identification of activities arguably "material" in character, both a Special Committee as well as the remainder of the directors of a reporting issuer will need to pay close attention to the substance of such disclosure obligations. Towards this end, a full review of Canadian law informing what constitutes a "material fact" and a "material change" is beyond the scope of this article. That said, a number of high-level points of particular importance to suspected or proven corrupt practices by reporting issuers or their representatives and special investigations into such suspected or proven corrupt practices remain worth highlighting.

One is the general principle that the concept of "materiality" built into both "material facts" and "material changes" requires that the fact or change is reasonably expected to have a significant effect on the market price of the securities of the issuer. ${ }^{150}$ Another is that "materiality" is a question of mixed law and fact that requires a contextual determination, ${ }^{151}$ and that it may not be premature to disclose actual events and developments on their consequences to a reporting issuer even if there remains uncertainty regarding their causes, future effects, financial impacts, or duration. ${ }^{152}$ Perhaps most importantly, whether the formation of a special committee to investigate suspected or proven liabilities (whether of a criminal nature or a civil nature) accrued by a reporting issuer in and of itself requires disclosure appears to remain an open question in Canadian securities law. ${ }^{153}$ That said, it does appear to be the case that, where the existence of a special committee is disclosed, such disclosure must include reasonable discussion of the mandate of the special committee. ${ }^{154}$ So too does it appear settled that reporting issuers are required to disclose any known investigations into the issuer's operations being conducted by regulatory authorities. ${ }^{155}$

For further discussion of director liabilities under securities laws in the context of corrupt practices, see section VIII below.

In the Matter of Coventree Inc, Geoffrey Cornish and Dean Tai, Ontario Securities Commission (Reasons for Decision, 28 September 2011) at para 149 [Coventree].

Ibid at paras 153-56, 368, referring to YBM Magnex, supra note 144 at para 94; Rex Diamond Mining Corp v Ontario Securities Commission, 2010 ONSC 3926 (Div Ct) at para 6 [Rex Diamond]. Towards this end directors would also do well to appreciate that "the test for the determination of a material change is objective, and does not depend on the subjective assessment or optimistic personal views of company executives" (Cornish v Ontario Securities Commission, 2013 ONSC 1310 at para 55 [Cornish]).

Coventree, supra note 150 at para 637.

Note that some US case law provides that uncharged criminal conduct or unadjudicated violations of law generally need not be disclosed. See YBM Magnex, supra note 146 at para 96 referring to US $v$ Mathews, 787 F2d 38 (2d Cir 1986); SEC v Chicago Helicopter Industries, 1980 US Dist Lexis 17214 (ND III 1980). See also In re Ramp Corp Secs Litig, 2006 US Dist Lexis 49579, Ded Sec L Rep (CCH) P93914 at 37; United States v Crop Growers Corp, 954 F Supp 335, 1997 US Dist LEXIS 708 at 24-26; Geoffrey Rapp, "On the Liability of Corporate Directors to Holders of Securities for Illegal Corporate Acts: Can the Tension between the 'Net-Loss' and 'No-Duty-To-Disclose' Rules be Resolved” (2001) Fordham J Corp \& Fin L 101.

YBM Magnex, supra note 144 at para 129.

Ibid at para 157. 
By way of example, on 8 August 2012, Nordion Inc., a TSX and NYSE listed provider of services and products for the prevention, diagnosis, and treatment of disease based in Ottawa, released a press release disclosing that it had begun "an internal inquiry and investigation of a foreign supplier and related parties" focusing on compliance with the CFPOA and the FCPA. ${ }^{156}$ Specifically, Nordion disclosed that:

\begin{abstract}
Through the Company's own internal review as part of its CFPOA compliance program, Nordion discovered potential compliance irregularities. As a result, the Company recently commenced an internal investigation of the possible compliance issues. These issues relate to potential improper payments and other related financial irregularities in connection with the supply of materials and services to the Company. The investigation is being conducted by outside legal counsel and external forensic and accounting firms who are experts in such compliance. These external advisors are reporting regularly to a Special Committee of the Board constituted to deal with this matter. ${ }^{157}$
\end{abstract}

In addition, Nordion disclosed that it had voluntarily contacted regulatory and enforcement authorities in both Canada and the US "to provide details of the matter and to advise that an internal investigation is underway," and that the "Company's external advisors have met with these authorities and will continue to provide reports to them as the investigation progresses.”158

Similarly, on 25 June 2012, Cardero Resources Corp., a Vancouver-based mining company listed on the TSX, NYSE, and FSE, released a press release disclosing that the company had recently been informed by the RCMP that it was the subject of an investigation following publications in Ghana alleging that the company had engaged in corrupt practices in securing its iron ore concessions in the country. ${ }^{159}$ Cardero further stated that it was cooperating with the RCMP and that it had undertaken its own "independent review" to verify the company's belief that it had "acted with best business practices in assisting [its] joint venture partner to compete for, and win, the right to explore and develop [its concession]."160 A second press release from Cardero followed on 13 January 2013 wherein the company disclosed that "the previously disclosed investigation by the [RCMP] with respect to the company's activities ... in Ghana has been closed and that no further action will be taken by the RCMP." 161 Cardero highlighted that the revelation of the RCMP investigation prompted the company to initiate "a robust internal investigation ... conducted by specialized external legal counsel,” the results of which the company shared with the RCMP. $^{162}$

Nordion, “Nordion Statement on Voluntary Disclosure,” online: Nordion <http://news.nordion.com/ phoenix.zhtml?c=68761\&p=irol-newsarticle\&ID=1723999>.

Ibid.

Ibid.

Cardero Resources Corp, "Cardero Maintains That it Followed Best Business Practices Regarding the Acquisition of Sheini Hills Iron Ore Project, Ghana” (25 June 2012), online: Cardero < http://www. cardero.com/s/news_releases.asp?DateRange=2012/01/01...2012/12/31> .

Ibid.

Cardero Resources Corp, “Cardero Reports Results of Ghana Investigation” (31 January 2013), online: Cardero <http://www.cardero.com/s/news_releases.asp?ReportID=568673>.

Ibid. According to the press release, the RCMP "praised the fulsome and comprehensive nature of the Company's investigation, and thanked Cardero for its cooperation in the matter.” 
That said, it is important to stress that the lessons of Griffiths Energy and its special investigation are not "a one size fits all” model: not all boards of directors should, or should reasonably be expected to, respond to suspected or proven corrupt practices by a corporation in the same manner as the board of Griffiths Energy. First of all, it is important to recognize the gravity of the corrupt practices engaged in by the former management of Griffiths Energy, namely the explicit undertaking to pay large sums to a high-ranking government official in pursuit of lucrative resources concessions. Secondly, it is important to recognize the deliberate, pre-meditated and sustained manner in which these corrupt practices were pursued by the some of the most senior of Griffiths Energy's former management. Lastly, it is important to recognize the sudden and near incontrovertible manner in which these corrupt practices were brought to light, such as, through the discovery by third party legal counsel of written and executed contracts establishing the payments to be made, who they were to be made to, on what conditions precedent.

Very few suspected or proven corrupt practices will be uncovered in such an explosive fashion. Rather, suspected or proven corrupt practices are far more likely to be identified in a gradual fashion, for example, beginning with initial suspicion followed by progressively directed and intensive investigation and analysis. In such circumstances, the reaction of the board need not be so swift, concentrated and concerted as was that of the board of Griffiths Energy. In fact, it is not necessarily even reasonable to expect that the board even be alerted to suspected or proven corrupt practices until they reach a certain materiality threshold. Rather, it is only reasonable for a board - once having instituted appropriate anti-corruption policies and procedures and associated implementation and enforcement systems — to be entitled to rely on such policies, procedures and enforcement systems to report to them as is appropriate material information pertaining to the corporation's anti-corruption compliance.

In the case of the initial identification of suspected or proven corrupt practices, such reasonable reliance may include the expectation that appropriate personnel (for example, the chief compliance officer) will diligently investigate the suspected or proven corrupt practices, including by enlisting appropriate expertise and assistance (for example, external forensic auditors, due diligence agents and/or legal counsel). Such reasonable reliance may also include the expectation that the results of such investigation and due diligence will be brought to the attention of the board in a timely and informed fashion. Where investigation and diligence identify material concerns, this information should be brought to the board as soon as possible once sufficiently analyzed and catalogued. However, where such investigation and diligence do not result in the identification of material concerns, it may only be reasonable that the concerns investigated — or even the fact that the investigation took place - only be presented to the board during the next compliance board meeting held by the directors (for example, an annual compliance audit review).

Once material anti-corruption non-compliance or suspected non-compliance is communicated to the board, the requirements of the director's duty of care will vary depending on the circumstances. Where grave corrupt practices such as those committed by the former management of Griffiths Energy are identified, the appropriate response will likely be the institution of a special committee armed with a large budget, broad mandate and appropriately qualified independent directors. However, where the corrupt practices identified are less severe than that of the Griffith Energy saga, a far less robust response may 
only be reasonable, including, for example: (1) the direction by the board that the compliance officer continue his or her investigation and report back to the board with additional findings; (2) the retention of special legal counsel to opine on the materiality of the corrupt practices committed by the corporation; or (3) that an external, third party audit of the corporation's anti-corruption policies and procedures be commissioned. What is of prime importance is that the board be sharply focused on the substance of their duty of care to the corporation given the nature and degree of the suspected or proven corrupt practices identified, and that the directors craft an informed, considered and prudent reaction in light of all the known facts.

\section{DIRECTOR LIABILITY UNDER SECURITIES LAWS FOR DISCLOSURE FAILURES}

While it was the guilty plea of Niko Resources which first fixed the attention of Canadian corporations on the seriousness of anti-corruption liability and risk mitigation, the recent tribulations of SNC-Lavalin have been sure to keep the spotlight on these issues. This is due in part to the RCMP's criminal investigation of SNC's operations in Libya, including numerous raids of SNC's offices in Montreal and Mississauga. ${ }^{163}$ This is also due in large part to a class action lawsuit levied against the company - as well as certain of its directors and officers - in connection with these same operations.

\section{A. DRYWALL V. SNC-LAVALIN GROUP INC.}

On 9 May 2012, the trustees of Drywall Acoustic Lathing and Insulation Local 675 Pension Fund instituted a class action against SNC-Lavalin Group Inc. (SNC) and various of its directors and officers under the Class Proceedings Act ${ }^{164}$ of Ontario. ${ }^{165}$ The class action followed the release by SNC on 28 February 2012 of a press release announcing that SNC had initiated "an Audit Committee investigation into \$35 million of payments that were documented to construction projects to which they did not relate” and subsequent filings: (1) confirming that the payments as well as the manner in which they were approved and processed violated a number of the company's policies and procedures, and (2) concluding that both SNC's internal controls over financial reporting and its disclosure controls and procedure suffered from a number of "material weaknesses" during the period in which the payments were made. ${ }^{166}$

Drywall alleges that the press release of 28 February 2012 led to a drop in SNC's share value of approximately 23 percent and the class action was therefore filed on behalf of all individuals and entities who purchased securities of SNC from 6 November 2009 through

See Paul Waldie, Ingrid Peritz \& Graeme Smith, "RCMP makes second search of SNC-Lavalin,” The Globe and Mail (13 April 2012), online: The Globe and Mail < http://www.theglobeandmail.com/news/ politics/rcmp-makes-second-search-of-snc-lavalin/article4100225/>; Tu Thanh Ha \& Ingrid Peters, "RCMP searching SNC-Lavalin headquarters," The Globe and Mail (13 April 2012), online: The Globe and Mail < http://www.theglobeandmail.com/globe-investor/rcmp-searching-snc-lavalin-headquarters/ article4210190/>.

164 SO 1992, с 6.

165 Drywall Acoustic Lathing and Insulation Local 675 Pension Fund (Trustees) and 6793094 BC Ltd v SNC-Lavalin Group Inc, Court File No 12-CV-453236CP (ONSC) (Statement of Claim of the Plaintiffs of 9 May 2012, amended as of 20 September 2012 and 1 November 2012) [Drywall v SNC-Lavalin]. Ibid at paras 49-51, 55. 
27 February 2012 (the "Class Period”) and seeks, amongst other things, compensatory damages in the amount of $\$ 1$ billion, pre and post judgment interest, and various costs. At issue are various alleged misrepresentations made by SNC in a series of the company's quarterly interim financial statements, annual financial statements, annual information forms, management's discussion, and analysis and proxy circulars.

\section{Drywall alleges that:}

During the Class Period, unbeknownst to the Class Members, SNC's business was conducted in an unlawful manner and in contravention of SNC's internal policies. In particular, in December 2009 and July 2011, SNC entered into agreements with "agents" with respect to projects on which SNC was working, pursuant to which SNC made payments totalling \$56 million to those “agents”. Although SNC purports not to know the purpose of such payments, their purpose was, in fact, to bribe foreign government officials and/or persons in Canada for the procurement of business by SNC. In any event, the agreements and the payment's thereunder violated SNC's [Policy on Commercial Agents/Representatives] and [Code of Ethics and Business Conduct]. ${ }^{167}$

Further to same, Drywall alleges that SNC, either explicitly or implicitly, made the following misrepresentations in various disclosure documents and filings issued during the Class Period:

(a) [that] SNC was a "socially responsible company" and a "responsible global citizen";

(b) [that] SNC had in place controls, policies and practices that were designed to ensure compliance with anti-bribery laws to which SNC is subject;

(c) [that] SNC had [internal controls over financial reporting and disclosure controls and procedures] that were properly designed and operating effectively; and

(d) [that] SNC's business was conducted in compliance with the [company's Code of Ethics and Business Conduct]. ${ }^{168}$

Importantly, Drywall alleges that:

Such statements were materially false and/or misleading because, during the Class Period, SNC was paying bribes to the "agents," or others with whom the "agents" contracted on behalf of SNC, in contravention of the [company's Code of Ethics and Business Conduct] and applicable anti-bribery laws and, in any event, the agency agreements and the payments to the “agents” thereunder violated the [company's Policy on Commercial Agents $\backslash$ Representatives] and the [company’s Code of Ethics and Business Conduct]. Further, SNC's [internal controls over financial reporting] and [disclosure controls and procedure] were not effective during the Class Period as a result of material weaknesses in the design and operating effectiveness of the [internal controls over financial reporting] relating to non-compliance with, and ineffective controls over 
compliance with, the [company's Code of Ethics and Business Conduct] and the [company's Policy on Commercial Agents\Representatives]. ${ }^{169}$

Similarly, Drywall alleges that a series of financial statements issued by SNC during the Class Period were "materially false and/or misleading in that they did not comply with [Canadian generally accepted accounting principles] and [International Financial Reporting Standards], as applicable, and were materially misstated due to the failure to disclose SNC's illegal acts." 170

\section{B. Securities Class Actions in Canada}

Securities class actions flowing from foreign corrupt practices can generally be expected to follow that trajectory evidenced by Drywall v. SNC-Lavalin. ${ }^{171}$ First, a company engages in foreign corrupt acts. The company then: (1) does not disclose the corruption; or (2) makes misleading or inaccurate statements regarding its compliance with anti-corruption laws. ${ }^{172}$ Next, a government body (such as the DOJ or the SEC in the US or the RCMP in Canada) begins investigating the foreign corrupt practices under the FCPA or the CFPOA. Alternatively, the media exposes the corrupt acts, as in the high-profile Wal-Mart case. ${ }^{173}$ Third, the investigation becomes public and the company's share value drops significantly, erasing a sizeable portion of the company's market capitalization. Finally, aggrieved investors bring a securities class action based on the company's lack of disclosure or misleading statements, often depressing share value even further.

While Drywall v. SNC-Lavalin is Canada's first instance of a securities class action related to foreign corrupt practices, it is part of a broader overall increase in securities class actions in Canada. ${ }^{174}$ This is primarily due to recent legislative amendments creating a statutory cause of action for participants in the secondary market (that is, shareholders who purchased their shares from a third party other than the entity that issued the shares) to join that

Ibid at para 9.

Ibid at para 10.

While Drywall $v$ SNC-Lavalin is the first Canadian example of a securities class action related to foreign corrupt practices, there have been several such actions in the US states that generally follow this pattern. See In Re Willbros Group, Inc Securities Litigation, Master File No 05-CV-1778 (Consolidated Amended Class Action Complaint, 9 January 2006) (SD Tex, Houston Div), online: SCAC <http:// securities.stanford.edu/1034/WG05_01/200619_r01c_0501778.pdf >; In Re Titan, Inc Securities Litigation, Master File No 04-CV-0676-LAB(NLS) (Class Action Consolidated Complaint, 17 September 2004) (S Dist Cal), online: SCAC <http://securities.stanford.edu/1030/TTN04-01/2004917 r01c_04676.pdf >; In Re FARO Technologies Inc Securities Litigation, Civil Action No 6:05-cv-1810ACC-DAB (Consolidated Second Amended Class Action Complaint, 22 February 2007) (MD Fla), online: SCAC <http://securities.stanford.edu/1035/FARO05_01/2007222_r01c_051810.pdf >; City of Brockton Retirement System v Avon Products, Inc, Master File No 11-CV-04665 (Amended Complaint For Violations Of The Federal Securities Laws (16 March 2012) (SD NY), online: SCAC <http:// securities.stanford.edu/1047/API00_01/2012316_r01c_11CV04665.pdf>.

Under securities legislation issuers have a duty to disclose all material facts capable of affecting the issuer's share value. See Securities Act, RSO 1990, c S.5 [OSA], ss 1(1) “material fact,” 75, 130(1), 138.3(1); Securities Act, RSA 2000, c S-4 [ASA], ss 1(gg) “material fact,” 146, 203(1), 211.03(1); Securities Act, RSBC 1996, c 418 [BCSA], ss 1(1) “material fact,” 63, 131-32.

City of Pontiac General Employees' Retirement System v Wal-Mart Stores, Inc, Master File No 12-CV00457 (Complaint for Violation of the Federal Securities Laws, 7 May 2012), online: SCAC <http:// securities.stanford.edu/1048/WMT00_01/201257_f01c_12CV00457.pdf>.

Bradley A Heys \& Mark L Berenblut, “Trends in Canadian Securities Class Actions: 2011 Update: Pace of Filings Grows, Pace of Settlements Slows” (NERA Economic Consulting, 2012), online: NERA $<$ http://www.nera.com/nera.../PUB_Recent_Trends_Canada_2011_0412.pdf >. 
statutory cause of action already available to investors in the primary market. ${ }^{175}$ These provisions came into force in Ontario in $2005,{ }^{176}$ and were followed by similar or identical provisions in each other province and territory. ${ }^{177}$ The significance of these statutory reforms cannot be easily overstated: under the previous common law regime of negligent misrepresentation it was necessary to prove reliance on an omission or misrepresentation by every single class member. ${ }^{178}$ However, this hurdle has now been dismantled by statutory language providing for deemed reliance on the omission or misrepresentation by each shareholder. ${ }^{179}$ Unsurprisingly, the number of securities class actions filed each year has more than doubled since the beginning of this game change in 2005, with the number of class actions alleging secondary market misrepresentation exhibiting particularly strong growth. ${ }^{180}$

Several recent plaintiff-friendly decisions in Ontario suggest that this upward trend in Canadian securities class actions is likely to continue. ${ }^{181}$ The twin decisions in Silver v. IMAX Corp. both set a low threshold to obtain leave and expanded the jurisdictional scope of the class that can be certified. The IMAX Certification Decision ${ }^{182}$ allowed the certification of a global class (that is, any shareholder of IMAX regardless of location) on the basis of a substantial nexus between the claim and Ontario. Specifically, the "real and substantial connection" requirement was held to be satisfied as: (1) IMAX was a reporting issuer under the Ontario Securities Act (OSA); (2) it traded on the TSX; (3) its head office was in Ontario; and (4) the allegedly misleading statements originated from its Mississauga, Ontario office. ${ }^{183}$ Furthermore, this was held to be the case notwithstanding that only 10 to 15 percent of IMAX's shareholders were Canadian at the time of the alleged misrepresentation. ${ }^{184}$ The IMAX Leave Decision, on the other hand, held that the statutory requirement of "reasonable probability of success at trial" may be satisfied where there is merely something more than a de minimis chance of success at trial, based on a reasoned consideration of the limited evidence available at the leave stage. ${ }^{185}$

OSA, supra note 172; ASA, supra note 172; BCSA, supra note 172.

See Bill 198, An Act to implement Budget measures and other initiatives of the Government, 3rd Sess, 37th Parl, Ontario, 2002, cl 185 (assented to 9 December 2002), SO 2002, c 22. Securities class actions for secondary market liability based on this statutory cause of action, whether in Ontario or elsewhere, are now commonly referred to as "Bill 198 cases."

See Bill 20, Securities Amendment Act, 2006, 2nd Sess, 26th Leg, Alberta, 2006, cl 52 (assented to 24 May 2006), SA 2006, c 30; Bill 28, Securities Amendment Act, 2007, 3rd Sess, 38th Parl, British Columbia, 2007, cl 20.

See McKenna v Gammon Gold Inc, 2010 ONSC 1591, 2010 CLB 4844 at paras 41-44, 128-163.

OSA, supra note 172, s 138.3(1); ASA, supra note 172, s 211.03(1); BCSA, supra note 172, ss 131(1), 132(1), 132.1(1). This "deemed reliance" clause existed for decades in the statutory cause of action for primary market liability (i.e. where the shareholder purchased the shares directly from the issuing company).

Heys \& Berenblut, supra note 174 at 2-4. However, it should be noted that a pronounced rise in the number of cases filed in 2011 was due to a number of cases filed against Chinese companies listed on North American exchanges. A rise in the number of cases filed against Chinese companies occurred in Canada as well as the US.

181 Securities laws in Canada generally follow Ontario's lead. Also, the great majority of securities class actions are brought in Ontario. See Heys \& Berenblut, ibid at 5.

182 Silver v IMAX Corp, [2009] OJ no 5585 (SCJ) (QL) [IMAX Certification Decision].

183 Ibid at paras 109-30. The Court acknowledged, however, that the misleading statements may also have emanated in part from IMAX's New York City office.

$184 \quad$ Ibid at para 109. Silver v IMAX Corp, [2009] OJ no 5573 (SCJ) (QL) at paras 324-25 [IMAX Leave Decision] interpreting and applying OSA, s 138.8(b). Note, however, that the British Columbia Supreme Court has adopted a more stringent test than in Ontario, stating that the "reasonable possibility" requirement is designed to do more than merely screen out frivolous, scandalous or vexatious actions. See Round v MacDonald, Dettwiler and Associates Ltd, 2011 BCSC 1416, 2011 CLB 25971 at para 76 considering BCSA, s 140.8(2)(b). The Court of Appeal largely upheld the motions justice's decision, but refused to comment on the "reasonable possibility" requirement (2012 BCCA 456, 2012 CLB 34469). 
Stretching its jurisdictional reach somewhat further, the Ontario Superior Court of Justice in Abdula v. Canadian Solar Inc., ${ }^{186}$ recently held the "real and substantial connection" test to be satisfied where the representative plaintiff lived in Ontario, bought shares of a company registered in Ontario, and used a computer in Ontario to purchase the shares. ${ }^{187}$ When Abdula was appealed, the Court of Appeal held that it was not necessary for the issuer's shares to be traded in Ontario or even in Canada. ${ }^{188}$ In Abdula, almost all of the company's operations and executives were located in the People's Republic of China, that the company's shares only traded on the US-based NASDAQ. ${ }^{189}$ Contrast this willingness on the part of Ontario courts to certify global class actions with the US Supreme Court decision in Morrison v. National Australia Bank Ltd., which limited the US courts' jurisdiction to "domestic transactions" (that is, limited the plaintiff class to shareholders who purchased their shares on a US stock exchange). ${ }^{190}$ Numerous commentators therefore expect Morrison to drive some litigants to pursue their class actions in Canada rather than in the US, and evidence to support such conclusions can already be identified. ${ }^{191}$

\section{Director Civil Liability for Disclosure FAILURES}

As illustrated by the claims against SNC, Canadian securities laws require that reporting issuers disclose material facts or material changes regarding their business, operations, or capital that would reasonably be expected to have a significant effect on the market price or value of any of the issuer's securities. Furthermore, securities statutes, including both the Ontario Securities Act and the Alberta Securities Act, provide investors with a statutory right of action against directors of a reporting issuer, among others (including, of course, the issuer), where a misrepresentation has been made either in a prospectus or in another document released by the issuer. ${ }^{192}$ Moreover, such a "misrepresentation" includes both: (1) an untrue statement of material fact; as well as (2) an omission to state a material fact. ${ }^{193}$

Defences are available to Canadian directors in respect of allegations of misrepresentation. However, these defences generally require that the directors are able to prove that they conducted a reasonable investigation into the matters surrounding the alleged misrepresentation prior to it being made. In respect of primary market disclosure, liability will be avoided where the director: (1) did not believe there was a misrepresentation; and (2) conducted a reasonable investigation such as to provide reasonable grounds for the belief that there had been no misrepresentation. ${ }^{194}$ Pursuant to the $O S A$, in determining what constitutes reasonable investigation or reasonable grounds for a belief that there had been no misrepresentation, the "standard of reasonableness shall be that required of a prudent person

Abdula v Canadian Solar Inc, 2011 ONSC 5105, 2011 CLB 23724 [Abdula ONSC], aff'd 2012 ONCA 211, 2012 CLB 6405 [Abdula ONCA].

Abdula ONSC, ibid at paras 21-22; see also Abdula ONCA, ibid at para 9.

Abdula ONCA, ibid at para 88.

Abdula ONSC, supra note 186 at para 4; Abdula ONCA, ibid at para 3.

561 US (2010) at 18; $130 \mathrm{~S}$ Ct 2869.

See Jennifer Brown, "The class action migration," (December 2012), online: Canadian Lawyer Magazine <http://www.canadianlawyermag.com/4441/the-class-action-migration.html>.

OSA, supra note 172, s 130(1); ASA, supra note 172, s 203(1); BCSA, supra note 172, ss 131-32.

OSA, ibid, s 1 (defining "misrepresenation" as both: (1) "an untrue statement of material fact"; as well as (2) "an omission to state a material fact"); ASA, ibid, s 1 ; BCSA, ibid, s 1.

OSA, ibid, s 130(5); ASA, ibid, ss 203(7), 204(3)(e); BCSA, ibid, ss 131(6), 132(5). 
in the circumstances of the particular case.”195 Towards this end, what constitutes a reasonable investigation may involve both objective and subjective considerations; that is, it may differ depending on the factual circumstances as well as the particular skills and responsibilities of a director. ${ }^{196}$

Similarly, the "reasonable investigation" defence available in respect of secondary market disclosure will be available to directors where they can establish: (1) that they conducted or caused to be conducted a reasonable investigation into the matter; and (2) that they had no reasonable grounds to believe that the misrepresentation was being made. ${ }^{197}$ Furthermore, this defence is available in respect of both misrepresentations in disclosure documents as well as failures to make timely disclosure. ${ }^{198}$ In determining whether a reasonable investigation was conducted and whether a director had no reasonable grounds to believe the misrepresentation was being made the courts will consider a non-exhaustive list of relevant circumstances. ${ }^{199}$ These include, inter alia: (1) the nature of the responsible issuer; (2) the existence, if any, and the nature of any system designed to ensure that the responsible issuer meets its continuous disclosure obligations; and (3) the reasonableness of reliance by the person or company on the responsible issuer's disclosure compliance system and on the responsible issuer's officers, employees and others whose duties would in the ordinary course have given them knowledge of the relevant facts. ${ }^{200}$ Lastly, directors should keep in mind that the courts have made clear that the "business judgment rule" will not protect good faith but incorrect disclosure decisions by directors. ${ }^{201}$

With these principles in mind, mitigating the risk of director civil liability to investors under securities laws will begin (much like risk mitigation in respect of a director's duty of care) with ensuring that the issuer has in place and enforces reasonably customized anticorruption policies and procedures. This is the case for two reasons. First, this should assist the company and the directors in preparing full, plain, and true disclosure of its anticorruption risk exposure as well as its corresponding anti-corruption policies, procedures, and enforcement practices. Secondly, this should improve the availability to the company and its directors of a "reasonable investigation" defence should potential civil liability to investors for misrepresentations in respect of corrupt practices actually be incurred.

In Drywall v. SNC-Lavalin, the majority of the plaintiffs' claims generally allege that SNC: (1) misrepresented that it was a responsible corporate citizen with strong corporate governance values and practices; (2) misrepresented that it had adequate controls, policies, and procedures to ensure accurate disclosure and financial reporting; (3) misrepresented that it had controls, policies, and procedures to ensure compliance with all Canadian and foreign laws applicable to its business, including the CFPOA; and (4) misrepresented that it and its employees acted in compliance with the company's code of ethics.

OSA, ibid, s 132. No equivalent provision exists in Alberta. However, the Alberta Securities Commission uses the same standard of reasonableness as in Ontario: see Re Kapusta, 2011 ABASC 322 at paras 36769, citing with approval YBM Magnex, supra note 144; BCSA, ibid, s 133. YBM Magnex, ibid at paras 178-79.

OSA, supra note 172, s 138.4(6); ASA, supra note 172, s 211.04(6); BCSA, supra note 172, s 132.1(5). OSA, ibid, s 138.4(6); ASA, ibid, s 211.04(6); BCSA, ibid, s 140.4(6)(b).

OSA, ibid, s 138.4(7); ASA, ibid, s 211.04(7); BCSA, ibid, s 104.4(7).

OSA, ibid, ss 138.4(7)(a), (e)-(f); ASA, ibid, ss 211.04(7)(a), (e)-(f); BCSA, ibid, ss 140.4(7)(a), (e)-(f). Coventree, supra note 150 at para 162. 
In contrast to the allegations levied against SNC, instituting and enforcing customized anti-corruption policies and procedures will first provide a company and its directors with the substance of the company's basic anti-corruption disclosure, that is, a description of the company's anti-corruption policies and procedures and the manner in which they are enforced. Such a description should not be overstated or exaggerated: it should be accurate and measured. However, instituting and enforcing such customized policies and procedures will ideally also provide a company and its directors with timely information regarding potential corrupt practices pursuant to which to judge whether further disclosure is necessary. Stated differently, such policies and procedures, if properly enforced, should provide a company and its directors the best chance of being alerted to any possible participation of its representatives or agents in corrupt practices of a degree actually requiring specific disclosure. Together this will mitigate against the company and its directors: (1) misrepresenting the scope or substance of its anti-corruption policies and procedures; and (2) failing to disclose material participation by the company, its representatives or agents in significant corrupt practices, if any.

Turning to the availability of a "reasonable investigation" defence where potential civil liability to investors for misrepresentations in respect of material corrupt practices is actually incurred, it is critical to recall that securities legislation imposes a number of standards and considerations to be applied and assessed where such a defence is claimed. In connection with misrepresentation in primary market disclosure (for example, in a prospectus), the courts will consider whether the "reasonable investigation" claimed meets the standard of "a prudent person in the circumstances of the particular case."202 In connection with misrepresentation in secondary market disclosure (including a failure to make timely disclosure), the courts will consider, inter alia: (1) the nature of the responsible issuer; (2) the existence of any system designed to ensure the issuer meets its continuous disclosure obligations; and (3) the reasonableness of reliance on the issuer's disclosure compliance system. $^{203}$

Properly enforced and reasonably customized anti-corruption policies and procedures should serve a number of positive purposes during the application and assessment of these defences. In connection with primary market disclosure, they will assist in establishing that the company's directors conducted an investigation as would "a prudent person in the circumstances of the particular case.” This will first be because such policies and procedures will be reasonably customized to the subject company's particular business and operations, taking into account those specific business units, operations, and individuals subject to the greatest risk exposure, that is, they will assess and target the company's particular circumstances. This will also be because such policies and procedures will provide a director asserting the "reasonable investigation" defence the best means of actually having conducted a due diligence investigation into the subject company's compliance with all applicable anticorruption laws prior to a primary market issuance, that is, they will provide both a marker and a road map pursuant to which directors can review and evaluate: (1) the company's anticorruption efforts; and (2) the results of those efforts, positive or negative. 
Similarly, in connection with secondary market disclosure (including a failure to make timely disclosure), properly enforced and reasonably customized anti-corruption policies and procedures should again assist in establishing that an investigation conducted by directors was reasonable in a number of meaningful respects. First, they will allow directors to argue that the investigation took into account the nature of the responsible issuer, that is, the nature of its operations as well as its geographical areas of operation and all those other companyspecific considerations examined when devising customized anti-corruption policies and procedures. Secondly, they will allow directors to argue that the investigation included a system designed to ensure that the issuer meets its continuous disclosure obligations, that is, that the investigation involved consideration of the implementation and enforcement of policies and procedures specifically addressing anti-corruption risk exposure. Lastly, they will allow directors to argue that they acted reasonably in relying on the issuer's disclosure compliance system and on those implementing and enforcing that system, that is, that they acted reasonably in relying on the company's enforcement of its anti-corruption policies and procedures and the manner in which such enforcement informs the company's honouring of its continuous disclosure obligations.

So what should such an investigation into the corporation's anti-corruption compliance reasonably entail, whether in the context of primary market or secondary market disclosure? First, it may be unreasonable to expect that any actual "investigation" of any significance ever take place. Rather, much as in the context of general compliance monitoring, it is only reasonable for directors - once having instituted appropriate anti-corruption policies and procedures and associated implementation and enforcement systems - to be entitled to rely on such policies, procedures and enforcement systems to report to them material information pertaining to the corporation's anti-corruption compliance in a timely manner. In this regard, the only "investigation" reasonably expected from a board in connection with disclosure decisions may be those regular audits built into the corporation's anti-corruption policies and procedures and the board's corresponding review and consideration of same, including follow-up questions and directions to management as may be prudent. Conversely, however, where actual anti-corruption compliance issues are identified by the corporation's compliance personnel, it is only reasonable to expect the directors to investigate those identified concerns in a diligent and deliberate fashion, including by means of some or all of those measures discussed in connection with the Griffiths Energy case (for example, retaining specialized legal counsel or forensic auditors), prior to or in association with the appropriate disclosure made.

\section{DIRECTOR REGULATORY OR QUASI-CRIMINAL LIABILITY FOR DISCLOSURE FAILURES}

In addition to civil liability under statutory causes of action for disclosure failures, Canadian directors should also appreciate that they face possible regulatory or quasi-criminal liability under securities laws in connection with inadequate disclosure of suspected or proven corrupt practices engaged in by reporting issuers. ${ }^{204}$ Furthermore, these thresholds are

204 Note that, in addition to the various provincial and territorial securities laws and related instruments, there also exist provisions of the Criminal Code intended to "aid in the regulation of securities and the capital markets in Canada” (Gordon E Kaiser, Corporate Crime and Civil Liability (Markham: LexisNexis Canada, 2012) at 312-18). 
lower in a number of important respects (and therefore more easily tripped) than those related to civil statutory causes of action for disclosure failures.

Section 122 of the OSA establishes three offences of a regulatory or quasi-criminal nature. ${ }^{205}$ These include making a statement that, "in a material respect and at the time and in the light of the circumstances under which it was made, is misleading or untrue or does not state a fact that is required to be stated or that is necessary to make the statement not misleading." 206 These also include the general offence of contravening Ontario securities laws, whether the OSA, the Regulations (including the Rules), or any decision by the Ontario Securities Commission (OSC) or one of its directors referring to the offending party. ${ }^{207}$ As such, one of the "central conventions of the OSA" actionable under section 122 includes "contraventions of disclosure requirements," including "the failure by a reporting issuer to disclose material changes in a timely manner."208 Furthermore, as reporting issuers effectively rely on their directors and officers for compliance with their timely disclosure obligations, the OSC may accordingly "use enforcement mechanisms against the directors and senior officers as well as the reporting issuers."209

Importantly, contraventions of section 122 can attract serious consequences, including in instances of the most egregious contravention, terms of imprisonment of as much as five years (less a day) or fines of as much as $\$ 5$ million, or both. ${ }^{210}$ Equally importantly, given that imprisonment is a possible consequence of a section 122 violation, due diligence defences are necessarily available to persons accused with a section 122 violation. ${ }^{211}$ As explained by Gordon Kaiser, "[i]n the case of an offence under section 122 ... due diligence means that the defendant could not have known that the statements were misleading, untrue or contained omissions." 212 This standard is composed of two separate parts. First, "[t]he defendant must demonstrate that he or she did not know that the statement was misleading, untrue or omitted a fact required to prevent the statement from being misleading." 213 Second, "[t]he defendant must show that it would have been impossible to know of the misleading nature of the statement, even with the exercise of reasonable due diligence." ${ }^{214}$ Also, "[w]hile not directly set out in the legislation, the defence of due diligence is also available to directors and officers as the Supreme Court of Canada has struck down absolute liability offences" which include imprisonment as a possible sanction. ${ }^{215}$

OSA, supra note 172, s 122(1)(b). See also ASA, supra note 172, s 194; BCSA, supra note 172, ss 155, 155.1, 155.2.

OSA, ibid, s 122(1)(c). See also Kaiser, supra note 204 at 303-304, stating that this "broad definition [of Ontario securities laws] provides the possibility for a large variety of contraventions of Ontario securities law.” See also ASA, ibid, s 194(1); BCSA, ibid, s 155(2).

Kaiser, ibid at 304.

Ibid at 312 .

OSA, supra note 172, s 122(1). See also ASA, supra note 172, s 194(1), providing that a person or company who contravenes the ASA is guilty of an offense and is liable to a fine of not more than $\$ 5,000,000$ or to imprisonment for a term of not more than 5 years less a day or both; BCSA, supra note 172 , s 155(2), providing that a person who commits an offense under the BCSA is liable to a fine of not more than $\$ 3,000,000$ or to imprisonment for a term of not more than 3 years less a day or both.

Kaiser, supra note 204 at 332.

Ibid at 332

Ibid at 332, referring to OSA, supra note 172, s 122(2).

Ibid at 333, referring to OSA, s 122(2).

Ibid at 332, referring to Reference re Motor Vehicle Act (British Columbia) S.94(2), [1985] 2 SCR 486. 
While this due diligence defence may, at first blush, appear identical in substance to those applicable to statutory causes of action for disclosure failures, a potentially very important distinction between the two requires careful consideration. This is that, while the defences available in respect of statutory causes of action for disclosure failures generally require merely that a director establish that he or she conducted or caused to be conducted a "reasonable investigation" into the subject matter of the disclosure failure, the defence available in respect of a section 122 violation requires that a director establish that he or she "in the exercise of reasonable diligence could not have known that the statement was misleading or untrue or that it omitted to state a fact that was required." 216 Therefore, while in the former case it is necessary to establish only that a reasonable investigation was in fact conducted, in the latter case it is arguably necessary to establish that no reasonable investigation (that is, not only the reasonable investigation actually conducted but also any other possible or alternative reasonable investigation that could have been conducted) would have identified or exposed the disclosure failure. ${ }^{217}$ This is of course a far stricter standard and one which could prove very difficult (if not unreasonably difficult) to meet if interpreted and enforced in this manner. ${ }^{218}$ Towards this end, in the context of a failure to adequately disclose corporate corrupt practices, enforcement authorities should appreciate and give due regard to the fact that material corporate malfeasance such as foreign corrupt practices is likely to be conducted by a small group of individuals in strict secrecy far from view of the board of directors and buried in multiple layers of bureaucratic, administrative, financial and/or technical disguise specifically designed to avoid detection. Stated differently, enforcement authorities should appreciate that, even if eventually unearthed, purposeful and premeditated corrupt practices may represent the epitome of those types of activities which no reasonable investigation, however conducted, may be capable of identifying in an around the time the activities (such as, the corrupt practices) actually take place.

It is also important for Canadian directors to appreciate that the OSC and Ontario courts have recognized two separate materiality standards applicable to disclosure obligations under the OSA. ${ }^{219}$ The first is the "market impact" standard which considers information to be "material" if it "would reasonably be expected to have a significant effect on the market price or value of an issuer's securities," and is the standard applicable to those statutory causes of action for disclosure obligations discussed above. ${ }^{220}$ The second materiality standard applicable for disclosure purposes is the "reasonable investor" standard, and is the standard applicable in deciding "whether disclosure was 'misleading' for the purposes of [certain]

OSA, supra note 172, s 122(2) [emphasis added]. See also ASA, supra note 172, s 194(2); BCSA, supra note 172 , s 168.1(2).

For a discussion of the application of the common law due diligence defence to OSA, s 122, including that such a defence may require "proof by the accused that the prohibited act was committed despite the exercise by the accused of all reasonable care in the circumstances to prevent it," see Borden Ladner Gervais LLP \& PG Findley, Securities Law and Practice, 3d ed, looseleaf (Toronto: Carswell, 2003) at § 22.12.1 [BLG/Findley].

This interpretation would essentially require that a negative assertion (as opposed to a positive assertion) be proven.

See Cornish, supra note 151; Andrew Gray, “Ontario Court Affirms OSC’s Disclosure Decision in Coventree" (3 April 2013), online: Torys < http://www.torys.com/Publications/Documents/Publication \%20PDFs/CCM2013-3.pdf >.

Gray, ibid. As discussed by Gray, "[i]t is also the standard applicable to certain regulatory allegations, including that an issuer failed to make timely disclosure of a material change." 
regulatory liability” under OSA section $122 .{ }^{221}$ Importantly, this is "a broader [and therefore lower] materiality standard based on what a reasonable investor would wish to know in making an investment decision."222 The "market impact" standard can also be understood to subsume the "reasonable investor" standard, given that not all "matters that may influence, and may therefore be material to, an investor in making [investment] decisions [will necessarily] have the probable effect of significantly altering market price or value of any securities of the issuer."223

Canadian directors should therefore appreciate that a different analysis and different standards may be applied to their disclosure decisions regarding suspected or proven corrupt practices depending on the circumstances in which such decisions are being considered or judged. On the one hand, where a director's disclosure decisions regarding suspected or proven corrupt practices are being scrutinized in the context of a civil action launched pursuant to a statutory cause of action, a consideration of prime importance will be that the disclosure decision satisfies the "market impact" standard, that is, that the disclosure included or did not omit information related to the suspected or proven corrupt practices reasonably expected to have a significant effect on the market price or value of the company's securities. On the other hand, where a director's disclosure decisions regarding suspected or proven corrupt practices are being scrutinized in the context of a regulatory proceeding launched by securities regulators, what may be of prime importance is that the disclosure decision satisfies the "reasonable investor" standard, that is, that the disclosure included or did not omit information related to the suspected or proven corrupt practices a reasonable investor would wish to know in making an investment decision. The result is that, even where a director's disclosure decision regarding suspected or proven corrupt practices avoids civil liability under a statutory cause of action, this does not guarantee that the disclosure decision will also avoid regulatory or quasi-criminal liability under securities laws should the decision ever be interrogated in this context. ${ }^{224}$

This of course creates a very difficult line for directors to walk, and which regulators should appreciate. Directors will obviously want to do their best to satisfy both the "market impact" standard and the "reasonable investor" standard in making disclosure decisions. That said, the realities of shareholder expectations and the capital markets make near certain

Gray, ibid. The reasonable investor test was first articulated by the US Supreme Court in TSC Industries Inc v Northway Inc, 426 US 438 (1976) at 449. Note, however, that the appropriate circumstances in which to apply the "reasonable investor" standard do not appear to be determined by a "bright line" test. See Re Biovail Corporation (2010), 33 OSCB 8914 (OSC) [Biovail] at paras 75 and 80 where the Court held the following:

In our view, the meaning of the words "in a material respect" is contextual and will vary depending on the nature of the document in which the statement is made. One would not necessarily apply the reasonable investor standard in assessing the materiality of a statement made (i) in a document that is not a disclosure document intended to be relied upon by investors in making investment decisions, (ii) in financial statements, or (iii) to an investigator carrying out a Commission investigation.... The reasonable investor standard is an objective test and applying it is ultimately a matter of judgment to be exercised in light of all the circumstances.

See Biovail, ibid at para 71. See also Cornish, ibid at para 79.

Towards this end, note that the Ontario Superior Court in Cornish referred favourably to the ruling of the OSC in YBM Magnex in advising that "materiality should be assessed objectively from the perspective of an investor and prospectively through the lens of expected impact," and this has been interpreted as a "useful articulation of the way an issuer should consider a disclosure question that encompasses both [the "market impact" standard and the "reasonable investor" standard].” See Cornish, ibid at para 47 and the interpretation of same by Gray, supra note 221. 
that a director who continually pushes for disclosure decisions informed primarily by the lower "reasonable investor" standard will likely find his or her board seat stripped in relatively short order. Furthermore, given the significant stigma attached to corrupt practices, this is likely even more the case in connection with disclosure decisions related to anticorruption compliance in which the market reaction to the disclosed information may be greatly disproportionate to the materiality of the corrupt practices committed. Regulators applying the "reasonable investor" standard to director disclosure decisions ex post should also appreciate that such decisions will have been made fearful of the fact that the premature disclosure of information pertaining to corrupt practices concerns, even if later assuaged, can irreparably taint a corporation's reputation as well as lead to immediate repercussions across the corporation's business operations in other jurisdictions incapable of remedy after the fact (for example, the failure to be awarded a government contract in an auction process the corporation would have otherwise won if not for the later-corrected disclosure).

The broader regulatory or quasi-criminal liability (as opposed to civil liability) faced by directors for direct involvement in disclosure failures is matched by other provisions of the OSA which attach liability to less direct involvement in disclosure failures. In particular, under section 129.2 of the OSA, "where an officer or director is found to have authorized, permitted, or acquiesced to the non-compliance of any securities law, the officer or director may be personally charged with violating that law." ${ }^{225}$ Stated differently, where a "company or person other than an individual commits an offence under section 122(1) of the OSA," then any director or officer of that company or person that authorized, permitted, or acquiesced in the commission of the section 122(1) offence "is himself or herself guilty of an offence under section 122(1)."226 Importantly, this can be the case "regardless of whether any proceeding has been commenced against the person or company that committed the offence directly."227 The term "acquiesce" will also be given its ordinary meaning by securities regulators, which shall mean "to agree or consent quietly without protest." 228 Lastly, as was held by the OSC in Coventree, director authorization, permission, or acquiescence in respect of a disclosure failures constitute a relatively low standard to meet. ${ }^{229}$

In the context of a failure to adequately disclose suspected or proven corrupt practices engaged in by a corporation, this means that, in addition to facing potential regulatory or quasi criminal liability in respect disclosure decisions in which they had a direct hand (for example, where the director was a principal author of a press release which omitted material information related to the suspected or proven corrupt practices), directors also face such liability where they acquiesced to the disclosure failure (for example, where a director fails to challenge and remedy the substance or completeness of a materially deficient press release addressing suspected or proven corrupt practices). In Coventree, for example, two of the company's directors were easily found to have authorized, permitted, or acquiesced to the company's contraventions of the OSA's continuous disclosure requirements (1) given their membership on Coventree's board of directors, strategic council, and disclosure committee; supra note 172, s 140.3(1)(c).

Kaiser, ibid at 358 [emphasis added].

Kaiser, ibid at 357.

Coventree, supra note 150 at para 766.

Ibid at para 767. 
(2) given the "knowledge, experience and access to information their roles implied"; and (3) given that they were "directly involved" in deciding whether Coventree should make disclosure of the material changes in the company's business held to have occurred. ${ }^{230}$

Lastly, while contraventions of OSA sections 122 and 129.2 may attract significant fines or terms of imprisonment, it is also important for Canadian directors to understand that securities regulators such as the OSC have the authority to impose a suite of additional administrative sanctions in respect of disclosure failures. Furthermore, these may be imposed in connection with administrative proceedings before OSC hearing panels "in the absence of a specific breach of the OSA" and pursuant to more flexible rules of evidence. ${ }^{231}$ Specifically, such administrative sanctions may be imposed under OSA section 127 when "it is in the public interest" to do so, including to contribute to "the goal of protecting investors and capital markets from the harm caused by a variety of "unfair, improper or fraudulent practices' and 'to foster fair and efficient capital markets and confidence in capital markets." "232 Towards this end, case law also states: (1) that "it is not necessary for the [OSC] to conclude that [an individual] acted wilfully or deceitfully in order to exercise its public interest jurisdiction"; and (2) that the "prior good character of [an individual] and the fact that they acted in good faith ... does not preclude a finding that their conduct was contrary to the public interest." 233

A number of the administrative sanctions available to Canadian securities regulators are of particular significance for directors. First, securities regulators may order a director to resign from his or her position as a director. ${ }^{234}$ Securities regulators may also issue an order prohibiting the director from becoming a director or officer of another corporation for a set period of time, ${ }^{235}$ a sanction "usually ordered when the impugned conduct is in relation to the respondent's role as a director or officer.”236 This sanction may also be imposed against individuals held to be de facto directors of a corporation in addition to officially appointed directors. ${ }^{237}$ Similarly, directors may be denied exemptions regarding distribution or registration requirements under securities laws under section $127 .{ }^{238}$ Finally, directors and

Ibid at para 770 .

Kaiser, supra note 204 at 343. Note, also, that Canadian courts will generally show great deference to decisions of securities regulators where commission rulings are challenged in the courts. See Committee for the Equal Treatment of Asbestos Minority Shareholders v Ontario (Securities Commission), 2001 SCC 37, [2001] 2 SCR 132 at para 49 [Asbestos]; Alberta (Information and Privacy Commissioner) $v$ Alberta Teachers' Association, 2011 SCC 61, [2011] 3 SCR 654 at para 34; Rowan v Ontario Securities Commission, 2012 ONCA 208, 110 OR (3d) 492 at para 79; Cornish, supra note 151 at paras 27-36. Kaiser, ibid at 343, referring to OSA, supra note 172, s 1.1. As discussed by Kaiser, such administrative sanctions are intended prospective and preventative in nature rather than punitive. See also Asbestos, ibid at para 45; Re Cartaway Resources Corporation, 2004 SCC 26, [2004] 1 SCR 672 at para 60; Cornish, ibid at paras 128-31.

Cornish, ibid at para 138.

OSA, supra note 172, s 127(1) paras 7, 8.1, 8.3. See also ASA, supra note 172, s 198(1)(d); BCSA, supra note 172, s 161(1)(d)(ii).

OSA, ibid, s 127(1) paras 8, 8.2, 8.4, 8.5. See also ASA, ibid, s (198(1)(e); BCSA, ibid, s 161(1)(d)(ii). Kaiser, supra note 204 at 353.

Ibid at 353.

OSA, supra note 172, s 127(1).3. See also ASA, supra note 172, s 198(1)(c); BCSA, supra note 172, s 161(1)(c). Kaiser, supra note 204 at 312 states that "[t] the denial of exemptions for a... director is an appropriate sanction for non-compliance with [disclosure requirements] where it is a responsibility of that... director to ensure such disclosure.” 
de facto directors may also be ordered under section 127 to disgorge any amounts obtained as the result of a violation of securities laws, including management draws. ${ }^{239}$

In total, Canadian directors should appreciate that they face liability in connection with disclosure failures regarding suspected or proven corrupt practices on a multiplicity of fronts, including both civil liability to investors under statutory causes of action as well as regulatory or quasi-criminal liability before securities regulators. Canadian directors should also appreciate that such regulatory and/or quasi-criminal liability (1) may be subject to lower standards (and therefore be more easily contravened); (2) may be more difficult to defend against (given more demanding due diligence defence requirements); and (3) may arise further to administrative proceedings independent of any corresponding civil actions. Lastly, and perhaps most importantly, Canadian directors should appreciate that depending on the circumstances, more may be expected of some directors than others by securities regulators.

While case law confirms that officers and directors of a reporting issuer are ultimately responsible for ensuring timely and accurate disclosure by the issuer, ${ }^{240}$ case law also provides that certain directors may be subject to higher standards than their peers. More may be expected of directors who have superior qualifications, such as experienced business people. ${ }^{241}$ More may be expected of inside directors, including, in particular: (1) directors with greater involvement in corporate decision making; (2) greater direct access to corporate information; or (3) greater involvement in co-ordinating, compiling, or vetting material corporate disclosure. ${ }^{242}$ More may also be expected of a director who is a lawyer, as a lawyer-director may potentially be in a better position to assess the materiality of certain facts. ${ }^{243}$ In the absence of grounds for suspicion, it is not improper for a director to rely on management to honestly perform their duties. ${ }^{244}$ So too is good faith reliance on legal advice that is fully informed, ostensibly credible, and within the lawyer's area of expertise consistent with the exercise of reasonable care by a director. ${ }^{245}$ That said, directors cannot remain passive and will be expected to ask tough questions regarding anti-corruption compliance not only of management but also of other directors. ${ }^{246}$ So, too, will directors have a positive duty to act when they obtain information or become aware of facts which might lead one to conclude that there may be an anti-corruption issue that may adversely affect the company, including carefully considering whether public disclosure of the matter is necessary. ${ }^{247}$

That said, Canadian securities regulators should also be careful to appreciate that directors of reporting issuers faced with proven or suspected material corrupt practices may face very difficult decisions regarding the appropriate amount of disclosure in the circumstances, if any. In the case of proven corrupt practices, it is important to appreciate that there exist many

Kaiser, ibid at 355, referring to OSA, ibid, s 127(1).10. See also ASA, ibid, s 198(1)(i); BCSA, ibid, s 155.1(b).

Coventree, supra note 150 at para 768.

YBM Magnex, supra note 144 at para 183.

Ibid at paras 184, 339; Coventree, supra note 150 at paras 768-69, referring to Soper, supra note 146 at paras $37-41$.

YBM Magnex, ibid at para 185.

Ibid at para 186.

Ibid at para 254.

Ibid at paras 286, 292.

Ibid at paras 182, 289. 
varying degrees of corrupt practices, many of which may be low level and relatively nonmaterial in nature and likely of little or no consequence. There is also an important difference between identified corrupt practices which are immediately suggestive of larger, more systemic anti-corruption compliance problems and those which do not immediately stir such greater concerns. In the case of suspected corrupt practices, it is also only reasonable to appreciate that these can prove very difficult to investigate and may lead only to unclear or incomplete conclusions regardless of the corporation's determination to seek resolution, particularly where individuals suspected to have participated in corrupt practices are no longer with the corporation and/or appear to have been assisted by third parties unwilling to assist with the corporation's inquiry.

As previously discussed, where corrupt practices remain merely suspected, it is also important for regulators to appreciate that premature disclosure by the corporation - given the stigma attached to corrupt practices - may result in reputational damage greatly disproportionate to the activities actually engaged in and/or result in immediate and irreparable consequences across the corporation's other business operations, even where the corrupt practices concerns are later confirmed to be far less material than originally feared (or even non-existent). Furthermore, the fact that additional information regarding previously suspected or identified but non-disclosed corrupt practices comes to light which aggravates the nature of the corrupt practices and thus clearly necessitates the disclosure of the corrupt practices at that time does not automatically mean that the earlier decision not to disclose the suspected or identified corrupt practices as they were then understood was in any way unreasonable or unjustified. Every case should be examined on its merits and with an even hand, and any resulting regulatory penalties should arguably be reserved for those directors acting either in conscious disregard for their obligations or in clear neglect of their obligations.

\section{Conclusion}

This article has attempted to advance discussion of (1) the particular liabilities faced by Canadian directors in connection with contraventions of the CFPOA which are particular to their status as directors of a corporation; and (2) the various risk mitigation strategies available to Canadian directors to mitigate against these potential liabilities. As noted by Kaiser, "[r]ecent legislation has marked an increase in expectations of director and officer responsibilities."248 Combined with the recent commitment of Canadian authorities to aggressively enforce and prosecute the CFPOA, the result is a legal and regulatory environment in which the actions and decisions of directors in respect of anti-corruption risk and compliance may to be closely scrutinized from a number of different perspectives and in a number of different venues.

One of these venues may be further to derivative shareholder action instituted against a director or group of directors on the corporation's behalf. As noted by Kaiser,

given the success of private litigants in competition law with class actions following closely on the heels of government prosecutions, we can expect this type of litigation in [Canada in] the bribery area. The cause of 
action will be similar to those that have been instituted in the U.S. The proceedings are based on a breach of fiduciary duty by officers and directors in failing to maintain adequate compliance programs to prevent bribery. $^{249}$

As in Drywall v. SNC-Lavalin, these venues may also include additional civil statutory actions instituted by investors following disclosure failures related to corrupt practices. Similar to Coventree, these venues may also include regulatory proceedings charging directors with regulatory or quasi-criminal liability further to disclosure failures related to corrupt practices.

Towards this end, the attention paid to anti-corruption risk and compliance by both enforcement officials and the broader market looks set to further increase in the short to midterm. In June of 2013, for example, Stephen Harper, the Prime Minister of Canada, announced a new disclosure initiative that will mandate that Canadian companies engaged in extractive industries, such as oil and gas and mining, disclose certain payments made to foreign and domestic governments and government bodies. ${ }^{250}$ As legal commentators have noted, this

initiative goes hand-in-hand with Canada's increased enforcement of its anti-corruption legislation, including the $[C F P O A] \ldots$... New requirements for Canadian companies in the extractive industries to report all payments to governments, in addition to imposing substantial compliance burdens, can also be expected to increase scrutiny and thereby significantly impact anti-corruption enforcement in Canada. ${ }^{251}$

This announcement was closely followed by the enactment of Bill S-14, which amended the CFPOA to, inter alia, (1) increase maximum prison terms from five to 14 years; and (2) significantly expand the reach of the Act by replacing "territorial" jurisdiction with "nationality” jurisdiction. ${ }^{252}$ Securities regulators have also recently made clear on a number of different occasions that they expect more detailed and more individualized disclosure from issuers operating in the resources sector as well as in emerging economies. ${ }^{253}$

Canadian directors should therefore take care to guard against the potential liabilities facing them in this new world order of anti-corruption risk and compliance. As discussed in this article, this may begin with anti-corruption policies and procedures customized to a

Ibid at $610-11$.

See J Boscariol, B Swick \& Z Masoud, “Canada announces new initiative for disclosure of payments to governments” (13 June 2013), online: McCarthy Tétrault <http://www.mccarthy.ca/article_detail. aspx?id=6334>.

Ibid. For a discussion of possible compliance problems raised but such reporting requirements, see Laura D Richman, Marc H Folladori \& Michael L Herman, "Digging Into SEC Mineral Disclosure Polices," online: Mayer Brown <http://www.mayerbrown.com/SEC-Mineral-Disclosure-Richman-FolladoriHermsen/>.

See Paul Blyschak, John Boscariol, Brenda Swick \& Robert Glasgow, "Significant Amendments Proposed to Strengthen Canada's Anti-Corruption Regime” (6 February 2013), online: McCarthy Tétrault <http://www.mccarthy.ca/article_detail.aspx?id=6169>.

See Jeff Gray, “OSC finds Ontario miners' disclosure ‘unacceptable,’” The Globe and Mail (27 June 2013), online: The Globe and Mail <http://www.theglobeandmail.com/report-on-business/industrynews/the-law-page/osc-finds-ontario-miners-disclosure-unacceptable/article12859344/ \#dashboard/follows/>; Ontario Securities Commission, “OSC Publishes Guide for Issuers Operating in Emerging Markets and provides update on Emerging Markets Review Recommendations,” online: Ontario Securities Commission <http://www.osc.gov.on.ca/en/NewsEvents_nr_20121109_osc-issuerguide.htm>. 
corporation's particular circumstances and business operations and designed to accommodate the reasonable involvement of directors, including through (1) periodic directorial review of the corporation's anti-corruption systems and compliance; and (2) timely directorial review of and response to material developments in the corporation's anti-corruption risk exposure or compliance. However, this may also require ongoing attention, analysis, prudence, and care, particularly given that current evidence indicates that courts, regulators and the market intend to hold directors to relatively high standards when it comes to the satisfaction of their duty of care as well as their duties to investors and securities markets. ${ }^{254}$ To paraphrase one critic of the performance of SNC's board of directors, Canadian directors of corporations with international interests will want to make sure that they cannot be characterized as "akin to skaters making intricate arabesques on a frozen lake, largely unaware of the teeming life underneath." 255

That said, it is also important that courts and regulators appreciate that foreign corrupt practices risk and compliance can present difficulties to corporations and their directors of a degree and complexity in many ways not previously experienced. Furthermore, the fact that foreign corrupt practices now appears to be a priority for Canadian enforcement authorities does not justify the over-enforcement of this regime by means of the application of unreasonable standards or expectations, whether in the criminal context or in the civil context. Canadian courts and regulators judging the actions and reactions of directors to anticorruption risk and compliance should therefore appreciate that anti-corruption risk represents only one among many other legal, commercial and financial risks against which directors must guard a corporation. So too should they appreciate that different anticorruption concerns will warrant different responses by the board depending on the circumstances, as well as in deliberation of both legal and business considerations. Lastly, Canadian courts and regulators should appreciate that the deliberately clandestine nature of corrupt practices can often make them incredibly difficult to both detect and clearly and/or confidently delineate. It is right to expect that Canadian directors mount reasonable defences against foreign anti-corruption risk. However, such expectations should also be tempered by the full measure of the possible challenges involved. requirements, "[i]f a decision is borderline, then the information should be considered material and [be] disclosed" (Cornish, supra note 151 at para 48, citing YBM Magnex, supra note 144 at para 518). 